\title{
Description of a new deer species (Cervidae, Mammalia) from the Early Pliocene of Eastern Europe, with a review of early dispersals and palaeobiogeography of the subfamily Cervinae
}

\author{
Roman Croitor \\ With 12 figures and 2 tables
}

\begin{abstract}
A new deer species, Praeelaphus australorientalis sp. nov., is described from the Kuchurgan beds dated back to the Lower Pliocene (European Lang Mammal Zones MN14 - beginning of MN15). The new species is characterized by a small "Dama-like" body size, relatively short braincase with respect to its breadth, and advanced morphology of four-pointed antlers. The morphological affinities and the systematical position of the new species and the genus Praeelaphus as a whole are discussed. The article also proposes a discussion of the Early Pliocene deer dispersals that changed the systematic composition of cervids in Western Eurasia and the palaeobiogeography of the subfamily Cervinae in Western Eurasia and the Indian Subcontinent. The dispersal capacity in plesiometacarpal Cervids is regarded as an evolutionary advantage correlated to the body size exceeding the body mass threshold of ca. $60 \mathrm{~kg}$.
\end{abstract}

Key words: Taxonomy, Praeelaphus, Cervinae, Kuchurgan gravel, body size, dispersal, palaeozoogeography.

\section{Introduction}

Early Pliocene cervids of Eastern Europe were the subject of several studies (JANOVSKAYA 1954; CZYZEWSKA 1968; KOROTKEVICH 1970; VISLOBOKOVA 1990; CROITOR 1999; CROITOR \& STEFANIAK 2009), however, some taxonomic, systematic, evolutionary, and palaeobiogeographic questions remain unanswered. The Kuchurgan fluviatile deposits from the Odessa Region of Ukraine yielded one of the most important collection of Early Pliocene (MN14 - beginning of MN15) cervid remains in Eastern Europe (KOROTKEVICH 1970, 1988; PEVZNER et al. 1996; VANGENGEIM et al. 1998). The Kuchurgan fluviatile deposits are confined to the watershed of Dniester and South Bug rivers and are exposed mainly on the flanks of the Kuchurgan River. These deposits represent medium and fine-grained sands with abundant lenses of gravel and pebbles (PEVZnER et al. 1996). Actually, "Kuchurgan" includes no less than a dozen of localities and, according to PEVZNER et al. (1996), spans a considerable time interval and can be subdivided in greater detail. Based on micromammals and magnetic polarity, PEVZNER et al. (1996) gave the exact biochronology for only two fossiliferous sites from the southern part of Kuchurgan deposits: Novaya Andriashevka (upper part of MN14) and Grebeniki-2, which is placed at the lower boundary of the Cochiti Subchron (the final stage of MN14). Large mammal remains come from the so-called "Kuchurgan gravel", which is placed in the upper part of MN14 and the initial part of MN15 (VANGENGEIM et al. 1998).

The opinions on the taxonomic content of the cervid assemblage from Kuchurgan deposits remain contradictory. KOROTKEVICH $(1970,1988)$ and PEVZNER et al. (1996) recognized in the composition of the Kuchurgan faunas several cervid species: Muntiacus pliocaenicus KOROTKEVICH, 1965, Eostyloceros pidoplitschkoi KOROTKEVICH, 1964, Pliocervus kuchurganicus KOROTKEVICH, 1965 (Paracervulus kuchurganicus fide PEVZneR et al. 1996), Croizetoceros ramosus (CROIZET \& JOBERT, 1828), Procapreolus cf. cusanus (Crolzet \& JoberT, 1828), and Paracervulus australis (DE SERRES, 1832). The revision of Early Pliocene cervid material from Eastern Europe carried out by CROITOR \& STEFANIAK (2009) reduced the list of cervid species from Kuchurgan deposits to only four (Procapreolus moldavicus, Muntiacus pliocaenicus, Eostyloceros pidoplitschkoi, Paracervulus australis). The antler fragments earlier described as Procapreolus cusanus, Procapreolus cf. cusanus, and Pliocervus kuchurganicus, according to our opinion, represent various stages of antler development of the Capreolinae deer Procapreolus moldavicus (JANOVSKAYA, 1954). This hog-deer-sized cervid was originally described by JANOVSKAYA (1954) as a transitional form between 
the primitive Late Miocene Cervavitus and true modern Cervus, Cervus (Rusa) moldavicus. However, a revision of the holotype of JANOVSKAYA's species (a partial juvenile female skeleton) revealed inaccuracies in the type skull restoration that caused misinterpretations of cranial morphology and wrongly defined systematic position (CROITOR 1999). The cranio-dental morphology of JANOVSKAYA's deer suggests that this is a primitive telemetacarpal deer of the genus Procapreolus (CROITOR 1999). KOROTKEVICH (1970: 130) failed to distinguish lower mandibles and postcranial bones of "Pliocervus kutchurganicus" and Procapreolus from Kuchurgan. Hence, the presence in the fauna from Kuchurgan deposits of a single smallto mediumsized species Procapreolus moldavicus is also supported by the uniformity of cranio-dental and postrcranial cervid material from Kuchurgan. Croizetoceros ramosus from the Kuchurgan fauna was mentioned by PEVZNER et al. (1996) with an erroneous reference to KOROTKEVICH (1988). Actually, KOROTKEVICH (1988) does not mention Croizetoceros in the Kuchurgan faunas and therefore this species should be excluded from the faunal list of this site. Even more, at present any hard evidence for the presence of Croizetoceros ramosus in Eastern Europe is still missing (CROITOR \& STEFANIAK 2009). The muntjac-like small-sized cervids "Muntiacus" pliocaenicus and "Eostyloceros" pidoplitschkoi, apparently represent the local (European)

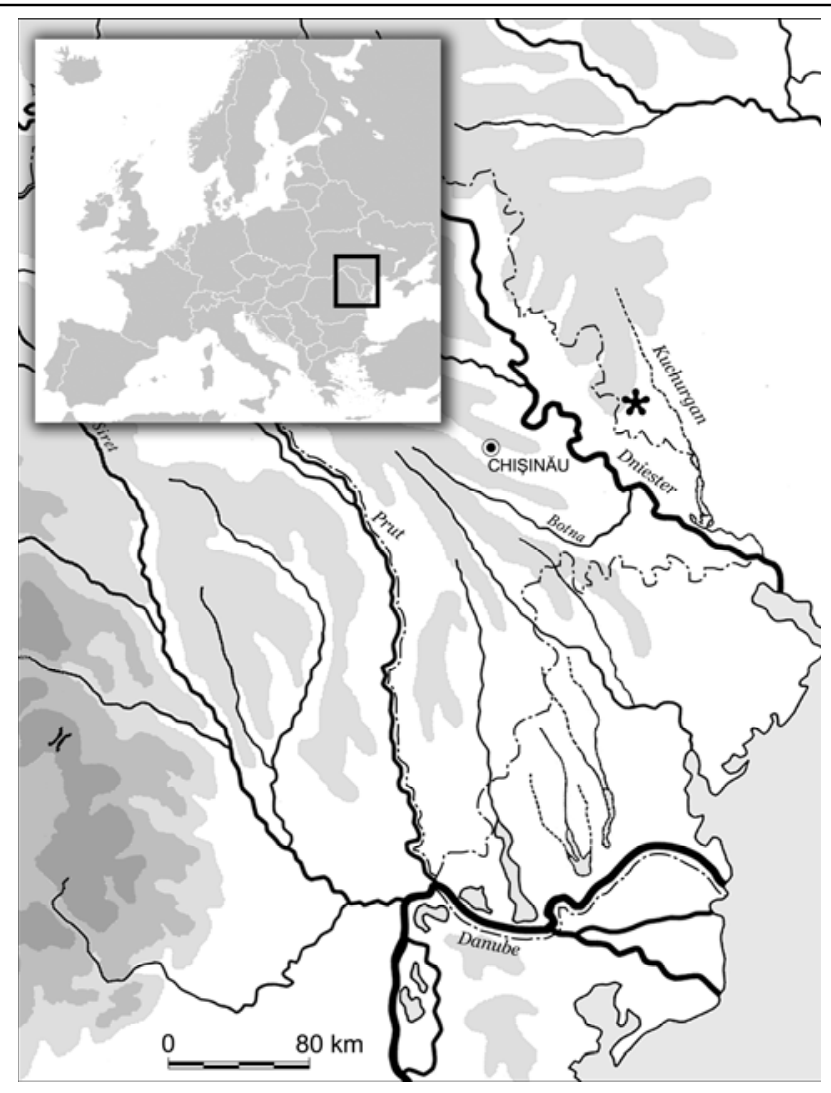

Fig. 1. Geographical location of the Velikoploskoe site (indicated by asterisk). radiation of dicrocerine deer (CROITOR \& STEFANIAK 2009). These species from the Kuchurgan deposits are still poorly known, since they are based on a few poor proximal fragments of antlers with pedicles and frontal bones. The differential characters between "Muntiacus" pliocaenicus and "Eostyloceros" pidoplitschkoi are limited to the relative length of pedicles (KOROTKEVICH 1970) and may simply represent two ontogenetic stages of one and the same cervid form: young individuals with relatively long pedicles are described as "Muntiacus" pliocaenicus, while older individuals with relatively short pedicles are known as "Eostyloceros" pidoplitschkoi (CROItor 2014). The taxonomy and phylogenetic relationships of Paracervulus australis from the Kuchurgan deposits, based on a right two-tined antler with high position of bifurcation and relatively short and thin pedicle (KOROTKEVICH 1970: 180, fig. 7), remains open. Therefore, the cervid fauna from Kuchurgan deposits includes the capreoline Procapreolus moldavicus (JANOVSKAYA, 1954), represented by remains of various ontogenetic stages, the dicrocerine "Eostyloceros" pidoplitschkoi KOROTKEVICH, 1964, the Muntiacus-like cervid "Muntiacus" pliocaenicus KOROTKEVICH, 1965, if this does not represent a juvenile form of the former cervid species, and the poorly known Paracervulus australis (DE SERRES, 1832).

The present work deals with the description of a new fallow-deer-sized cervid form from the Kuchurgan deposits. The fossil specimen under study is a wellpreserved braincase with partially preserved antlers retrieved from the outcrops situated near the village Velikoploskoe, Odessa Region, Ukraine (Fig. 1). The 
gravel pieces encrusted on the surface of the skull suggest that the specimen delivers from a fossiliferous gravel lens of the Kuchurgan fluviatile deposits. Unfortunately, a more exact stratigraphic information is unavailable.

\section{Research method and material}

The antlered braincase OF24995 from Velikoploskoe (= Velykoploske [in Ukrainian]; = Velikoe Plioskoe [in Russian]) is at display in the public exhibition of the Palaeontological Section of the National Museum of Ethnography and Natural History, Chișinău (Moldova). Comparative fossil material includes the cervids from the Lower Pliocene sites of Malușteni, Romania (curated at the Institute of Speleology "Emil Racovița", Bucharest, Romania) and Weze-1, Poland (curated at the Institute of Zoology, University of Wrocław, Poland), as well as the Villafranchian cervid remains from Perrier-Etouaires, France (curated at the National Museum of Natural History, Paris, France), and Ponte a Elsa and Olivola, both sites in Italy (curated at the Museum of Geology and Palaeontology, University of Florence, Italy). The craniometrics data of Megacervocerus rhenanus from Ceyssaguet (collection numbers are indicated with CEY: Table 2) are adapted from CROITOR (2006).

The type material of the following species was directly studied and measured:

Cervus perrieri CROIZET \& JOBERT 1828 (neotype: a right almost complete antler attached to frontal pedicle, no collection number; the National Museum of Natural History, Paris; designated, figured and described in HEINTZ 1970);

Cervus warthae CZYZEWSKA 1968 (holotype: a damaged skull without antlers of a young adult male, Nr. 1; the Institute of Zoology of the University of Wroclaw, Poland);

Pseudodama lyra AzZAROL 1992 (holotype: a frontlet of young male bearing a pair of complete antlers, IGF1933v; Museum of Geology and Palaeontology, University of Florence);

Cervus pardinensis CROIZET \& JOBERT 1828 (neotype: a left almost complete shed antler, no collection number; the National Museum of Natural History, Paris; designated, figured and described in HEINTZ 1970).

The skulls of other fossil and modern deer used in the present study as comparative material are curated at the following palaeontological and osteological collections: the Geological and Palaeontological Museum of University of Florence (labelled with acronym IGF); the Zoological Museum "La Specola" of the Natural History Museum of Florence (collection numbers start with " $\mathrm{C}^{\prime}$ ); the Natural History Museum of London (collection numbers start with "BM"); the National Museum of Natural History, Paris (collection numbers are marked here with " $\mathrm{P}$ "); the National Museum of Ethnography and Natural History (NMENH) (Table 2). The estimation of relative length of the neurocranium proposed in the present work is based on the ratio between bregma-opisthocranion length and maximal braincase width in females of braincase or braincase with behind pedicles in males. Those measurements are easily available in fragmented cranial material and hardly depend on the ontogenetic developmental stage, since the chosen craniometrics points are stable. According to MYSTKOWSKA (1966), the breadth of the neurocranium and bregmaopistocranion length are the most stable measurements in modern red deer and increase constantly and slowly during the animal's life. The sexual dimorphism in the relative braincase length is poorly expressed in mature age group of modern red deer (MYSTKOWSKA 1966). The frontal breadth may be influenced by divergence and robustness of pedicles that change with animal's age and therefore is onthogenetically biased and unsuitable for relative braincase calculation. The relative length of the neurocranium as 
calculated as the ratio between the braincase width measured behind pedicles and the bregmaopistocranion length is accepted here to describe braincase shape. The ratio between frontal breadth and braincase breadth is another character studied here. The cranial anatomical points used in this study are adapted from VISLOBOKOVA (1990). The body mass estimation based on cranial measurement variables used for species characterizations is adapted from JANIS (1990).

\section{Systematic palaeontology}

Family Cervidae Goldfuss, 1820

Subfamily Cervinae Goldfuss, 1820

Genus Praeelaphus Portis, 1920

Genus definition (after CROITOR 2012, modified): Deer of the size of modern European red deer and fallow deer. Pedicles of moderate length (postero-median length of pedicle in adult males does not normally exceed its diameter) and slightly compressed antero-posteriorly. Fully grown antlers are large relatively to the animal size, four-pointed. The first tine is situated above the burr at a distance larger than the diameter of the antler base. The antler beam often forms well-expressed flattened extensions in the areas of ramification. The transversal section of the beam below the second tine is not regular, often pyriform or ovoid. The beam above the second tine is significantly compressed and forms an extended flattening with frontal or parasagittal orientation. Correspondingly, the distal bifurcation may be oriented in the frontal or parasagittal plane. The dentition is primitive: $\mathrm{P}_{4}$ is generally simple, with a low degree of molarization, the lower premolar series is relatively long compared to molars and longer than in Cervus and Dama.

Type species: Cervus perrieri CROIZET \& JOBERT, 1828 ( = C. etueriarum CROIZET \& JOBERT, 1828; = C. issiodorensis CROIZET \& JOBERT, 1828); MN16b, France (see HEINTZ 1970 for the neotype designation, the emended diagnosis, and the description).

Taxonomical remarks: PORTIS (1920: 133) proposed the subgenus Cervus (Praeelaphus) for the Early Villafranchian species C. arvernensis CROIZET \& JOBERT, 1828, C. perrieri CROIZET \& JOBERT, 1828, and C. etueriarum CROIZET \& JOBERT, 1828.

Pomel (1853) published the first brief description of deer species (Cervus perrieri, C. etueriarum, and C. issiodorensis) based on fossil remains from Perrier figured by CROIZET \& JOBERT (1828). According to HEINTZ (1970), Cervus etueriarum is based on juvenile antlers of $C$. perrieri, however, he did not find in the collection stored in Paris any antler that rigorously correspond to the specimens figured by CROIZET \& JOBERT (1828). HEINTZ (1970) found in the collection stored in Paris one specimen (a complete antler) belonging to C. issiodorensis and figured by CROIZET \& JOBERT (1828: pl. 1 [27], fig. 1). According to HEINTZ (1970), this antler represents a morphological variant of $C$. perrieri. There are two other specimens labelled as types of $C$. issiodorensis CROIZET \& JOBERT, 1828 and stored in the collection of Palaeontological Museum of the University "Claude Bernard" Lyon 1. The basal part of a right shed antler Nr. 211214 from Lyon perfectly corresponds to the figure 2 on pl. 1 [27] in CROIZET \& JOBERT (1828). Its measurements are very close to those of the neotype of $C$. perrieri (Table 1). The measurements of the right astragalus Nr. 211205 (CROIZET \& JOBERT 1828: fig. 14, pl. 2 [28]; L $\max =60.1 \mathrm{~mm}$, DLM dist $=37.8 \mathrm{~mm}$ ) are very close to the mean values of the perrieri-ardei sample from Etouaires described in HEINTZ (1970). Some other remains ascribed to $C$. issiodorensis, in the opinion of FEJFAR et al. (2016: fig. 7b) belong to Metacervocerus pardinensis. Cervus arvernensis, which also was included by PORTIS (1920) in Praeelaphus, apparently, is a name created by BRAVARD but never published and described afterwards (LESSON 1836: 259). POMEL (1853: 112) did not give a definition for this species name, since, according to his opinion, " $C$. arvernensis est connu par des bois 
trop irréguliers pour ne pas être anomaux; l'espèce est incertaine". HEINTZ (1970) placed Cervus perrieri in the arbitrary group Cervus sensu lato, therefore the question of its systematical position remained open. Cervus (s. I.) perrieri is a plesiometacarpal deer with archaic "Rusa-like" cranial morphology but with quite advanced and specialized antlers (HEINTZ 1970; CROITOR \& STEFANIAK 2009) that, apparently, does not belong to the lineage of the true modern Cervus elaphus and therefore a new taxonomical solution was proposed (CROITOR 2012): the genus Praeelaphus PORTIS, 1920 with its type species Cervus perrieri. Praeelaphus includes archaic Pliocene and Pleistocene deer from Western Eurasia and belongs to the early evolutionary radiation of the Cervinae group. GRUBB (2000) supposed that Praeelaphus PORTIS may be synonymous with Metacervocerus DIETRICH, however, these genera (originally established as subgenera) are based on two different valid and recognized species: Cervus perrieri and C. pardinensis, respectively. Therefore, PORTIS' Praeelaphus is an available genus name, with Cervus perrieri as its type species.

Besides Praeelaphus perrieri from the Early Villafranchian of France, the genus also contains Praeelaphus lyra (= Pseudodama lyra AzZAROLI, 1992) from the Early Villafranchian of Italy based on an antlered frontlet of a young individual and Praeelaphus warthae (CZYZEWSKA, 1968) from the Ruscinian assemblage of Weze1 , Poland. The Polish species is characterized by a somewhat smaller body size and is based on a poorly preserved skull of a young male associated with very fragmented antler remains (CROITOR \& STEFANIAK 2009). The close affinity between Praeelaphus warthae and Praeelaphus perrieri is demonstrated by antler fragments from Weze-1: antler beam fragments with irregular ("pyriform" according to HEINTZ 1970) shape of transversal section, flattened extensions in the area of ramifications, and a frontally oriented flattened distal portion of the antler with perpendicularly set with respect to the beam flattening middle tine (CROITOR \& STEFANIAK 2009).

AZZAROLI (1992) regarded Pseudodama lyra from the Early Villafranhcian of Ponte a Elsa as a quite advanced representative of the genus Preudodama that included several small-sized "Dama-like" deer from the Late Pliocene and the Early Pleistocene of Europe. The original definition of Azzaroli's species was based only on general antler construction. The incipient third ramification of the left antler in Pseudodama lyra was regarded as a distinguishing character of this species (AzZAROLI 1992). The rather superficial definition of the species from Ponte a Elsa provoked contradictory opinions. DE Vos et al. (1995) regarded Pseudodama lyra as a junior synonym of Cervus rhenanus (= Metacervocerus rhenanus). CROITOR (2006) included Pseudodama lyra in the synonymy of Cervus nestii (AzZAROLI, 1947) taking into account the insipient frontally oriented third ramification in combination with the apparently juvenile age of the holotype IGF1394v of Pseudodama lyra. However, a more careful study of the holotype's morphology revealed the irregular (pyriform) transversal section of the proximal part of the antler beam and its strongly flattened distal portion (above the second tine). The observed characters strongly remind of the specific antler morphology of Praeelaphus perrieri and distinguish the cervid from Ponte a Elsa from Metacervocerus rhenanus with simple three-pointed anters characterized by regular circular transversal section of beam, as well as from Cervus nestii with four-pointed antlers characterized by a circular crosssection of antler beam and lacking the distal blade-like flattening of the beam (CROITOR 2014). The peculiar antero-posterior compression of pedicles in the specimen from Ponte a Elsa (Table 1) also distinguished this cervid form from Metacervocerus rhenanus and Cervus nestii, which are characterized by cylindrical or slightly compressed from the sides pedicles (CROITOR 2006). The Early Villafranchian Age of the antlers from Ponte a Elsa may even take us a step further and suggest a possible synonymy between Praeelaphus perrieri and P. lyra.

Therefore, Praeelaphus perrieri, $P$. lyra, and $P$. warthae are very close to each other and may be even synonymous. Nonetheless, reliable diagnostic characters are not available for $P$. lyra (the holotype is a young individual, which is the only known specimen of the species) and concern only moderate difference 
of body size in the case of $P$. warthae, which is based on a very fragmented fossil material. Thus, a conclusion regarding synonymy in this case cannot be made at the moment.

\section{Praeelaphus australorientalis sp. nov.}

Etymology: "australis", southern (Lat.), "orientalis", eastern (Lat.). The species name refers to the Southeastern Europe where it fossil remains were discovered.

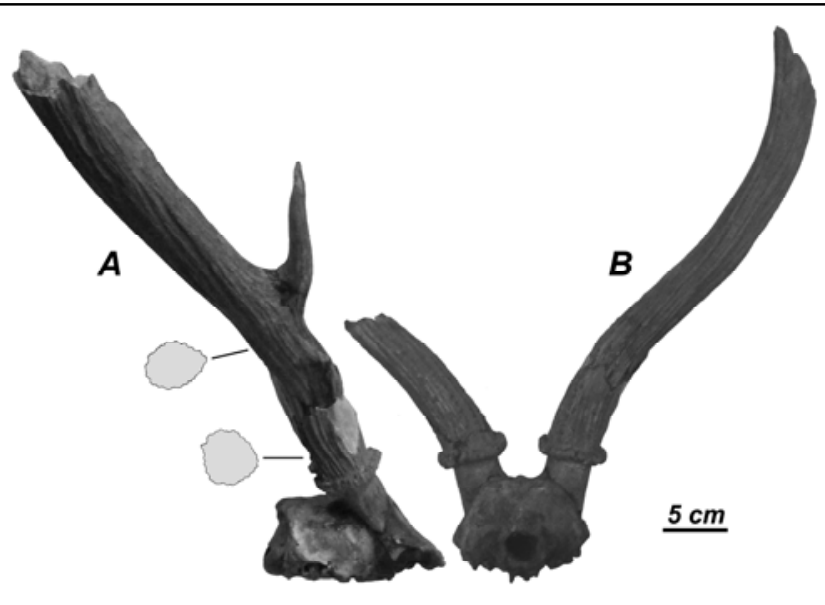

Fig. 2. Praeelaphus australorientalis sp. nov., the antlered skull OF24935 (holotype): A - side view with transversal sections of antler; $\mathbf{B}$ - posterior view.
Holotype: The antlered skull OF24995 with the main part of right antler, the basal part of left antler (Figs. 2-4, 6), and the distal detached fragment of left antler (Fig. 5). The holotype is stored in the palaeontological collection of the National Museum of Ethnography and Natural History of Chisinau (Moldova).

Additional material: Basal fragment of antler with pedicle Nr. 231 (Fig. 7) from Berești (Romania). The specimen is stored in the Institute of Speleology "Emil Racovița", Bucharest (Romania).

Type locality: Velikoploskoe Village (= Velikoe Ploskoe), Odessa Region (Ukraine).

Type horizon: Gravel lenses of the Kuchurgan fluviatile deposits.

Distribution: Early Pliocene, MN14 - beginning of MN15, Southeastern Europe (Ukraine, Romania).

Diagnosis: A medium-sized deer (close to the body size of modern fallow deer Dama dama) with a rather long braincase (the bregma-opisthocrnion distance is longer than the braincase breadth behind pedicles in males), comparatively narrow frontal bones in males (the braincase breadth measured behind pedicles attains ca. $80 \%$ of the frontal constriction before the pedicles), robust and moderately long pedicles (the length of the pedicle in mature males attains ca $2 / 3$ of the pedicle lateromedial diameter), small bullae tympani characterized by irregular shape and a short auditory tube, and robust antlers with four tines. The first and the second tines are inserted on the anterior side of the antler beam. The first tine is situated very high above the burr (the height of the first ramification exceeds more than two times the diameter of the basal part of antler beam). The antler segment between the first and the second tines is comparatively short (shorter than the height of the first ramification). The distance between the second and distalmost third ramification is three times longer than the distance between the first and the second ramifications. The basal segment of antler beam (below the first ramification) is regularly circular. The beam segment between first and second ramification has a longitudinal keel on the anterior side. The antler beam between the second and the third ramifications is significantly flattened, oriented in the parasagittal plane and terminated with a distal bifurcation. The anterior tine of the distal bifurcation is stronger and represents a continuation of the antler beam axis. 


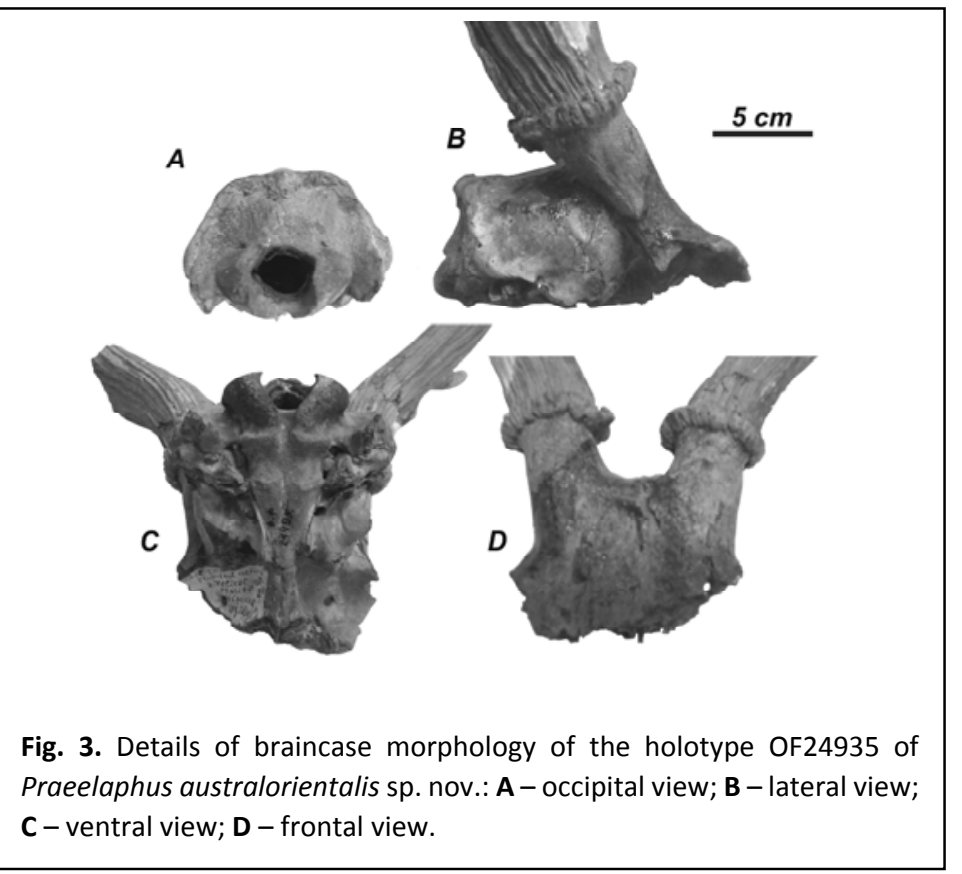

Differential diagnosis: Unlike
Metacervocerus

Praeelaphus australorientalis is

characterized by more robust antlers with four tines and flattened distal portion of the antler beam. Unlike Praeelaphus perrieri and P. lyra, $P$. australorientalis is characterized by a very short antler segment between the first and the second ramifications, a relatively long antler segment between the second and the third ramifications, a very high position of the first ramification, a regular circular (not ovoid) transversal beam section below the first tine. Unlike P. perrieri, P. lyra, and $P$. warthae, $P$. australorientalis is characterized by a parasagittal (not frontal) orientation of the flattened distal segment of the antler. Unlike $P$. warthae, $P$. australorientalis is characterized by relatively narrow frontal bones with respect to the braincase breadth and smaller bullae tympani with irregular shape.

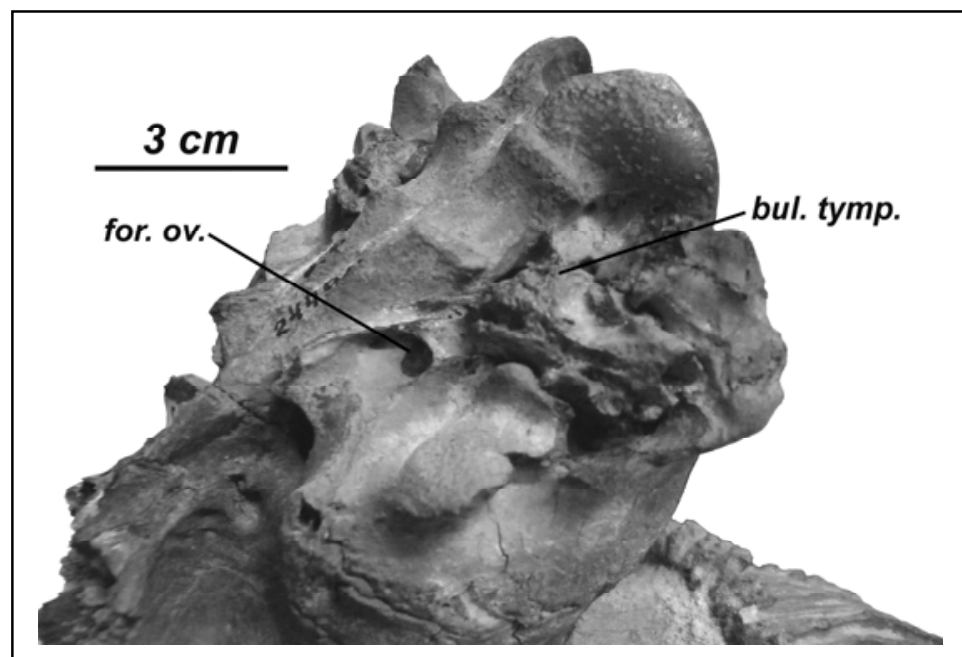

Fig. 4. Praeelaphus australorientalis sp. nov.: oblique view of the basioccipital region of the holotype OF24935.
Description: The antlered braincase OF24995 belongs to a medium-sized cervid similar in size to the modern fallow deer (Fig. 2). The greater part of the left antler is destroyed, only its proximal portion $(150 \mathrm{~mm}$ of total length) is preserved. There is also a distal fragment of left antler that apparently belongs to the same individual and represents a part of the antler beam between the second tine and the third (distal) bifurcation (Fig. 5). The right antler is better preserved, except for its first tine and distal portion. Antlers are relatively robust, lyre-shaped (Fig. 2B).

The shape of the cross-section of the antler base is circular and just slightly compressed in anteroposterior direction. Antler burrs are well developed and strong. The antler surface is densely covered with sharp longitudinal ribs and furrows. The surface of the median and posterior sides of the proximal portion of the antlers are sculptured with graininess and tubercles. The first tine of the better preserved right antler is situated very high relative to the burr: the height of the first ramification is ca. $105 \mathrm{~mm}$. 
The second tine is inserted on the anterior side of the beam at a short distance from the first tine: the length of antler segment between the first and the second ramifications is $78.0 \mathrm{~mm}$. The second tine is cone-shaped and rather short and has a circular transversal section. Its length amounts to $61.0 \mathrm{~mm}$, and the transversal diameter at the base amounts to $18.7 \mathrm{~mm}$. The angle of second ramification amounts to $35^{\circ}$.

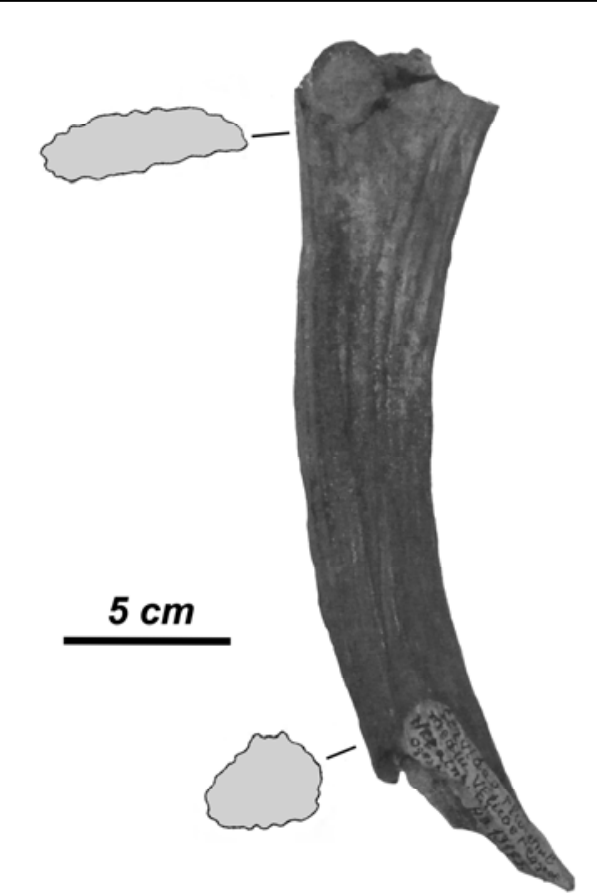

Fig. 5. Praeelaphus australorientalis sp. nov.: distal fragment of left antler of the holotype OF24935 with transversal sections.
The distal portion of left antler is a beam segment between the second and the third ramification that ends in a distal bifurcation (Fig. 5). The cross-section of the proximal end of the fragment is ovoid in shape with a sharpened posterior side $(\mathrm{DAP}=34.4 \mathrm{~mm}$; DLM $=32.7 \mathrm{~mm}$ ). The antler beam extends antero-porteriorly above the second ramification and becomes fairly flattened toward the third ramification. The thickness of the antler beam in the area of the distal bifurcation is $25.2 \mathrm{~mm}$. The anterior tine of distal bifurcation is more robust (its transversal diameter at the level of bifurcation attains $24.8 \mathrm{~mm}$ ) and represents a continuation of the beam axis. The posterior tine is thinner (its transversal measurement at the same level amounts to $20.1 \mathrm{~mm}$ ) and slightly deviates posteriorly from the axis of the main antler beam. The median side of the distal antler portion is rather flat, while the lateral side is convex. The total length of the distal fragment of the left antler attains $235 \mathrm{~mm}$, while the length of the left antler beam segment between the second and the third ramification amounts to $233 \mathrm{~mm}$. The length of the right antler segment between the second and the third ramifications exceeds $200 \mathrm{~mm}$.

The pedicles are moderately long (Fig. 3B, D) with a circular cross-section and are slightly compressed in the anteroposterior direction. The pedicles are deflected posteriorly (therefore, they are situated in the plane of frontal bones) and diverge slightly: the angle of divergence formed by pedicle axes is $40^{\circ}$. The frontal bones are rather narrow and slightly depressed between the frontal suture and their lateral margins. The roof of the braincase is slightly convex, the sigmoid suture between the temporal and occipital bones is trapezoidal. The basioccipitale is pentagonal-shaped due to a moderate extension of the pharyngeal tuberosities (Fig. 3C). The foramen ovale is not particularly large and oval (its maximal diameter amounts to $4.6 \mathrm{~mm}$ ). The maximal diameter of the foramen ovale is set obliquely with respect to the sagittal plane as in advanced Old World deer (VISLOBOKOVA 1990).

The bullae tympani are quite small and characterized by an irregular shape (antero-posterior measurements: sin, $12.9 \mathrm{~mm}$; dx, $13.2 \mathrm{~mm}$ ), without any apical thorn or spike (Fig. 4). The shape of the bullae tympani is quite similar to that of Axis axis as reported by Pососк (1943). The external auditory tube is rather short; the measurement from the auditory orifice to the inner anterior edge of the bulla tympani amounts to $30.4 \mathrm{~mm}(\mathrm{dx})$ and $27.5 \mathrm{~mm}(\mathrm{sin})$ and is about $25 \%$ shorter than in the modern primitive Cervini Axis axis and Hyelaphus porcinus, according to the data provided by Pocock (1943).

Although both tympanic bullae are present, the left os temporale is damaged, therefore a direct observation of the post-glenoid foramen morphology is possible: the postglenoid foramen is closed from 
the medial side by the bony bridge of squamosal bone. This character distinguishes plesiometacarpal cervids from telemetacarpal cervids (BOUVRAIN et al. 1989) and confirms the attribution of the deer under study to the subfamily Cervinae.

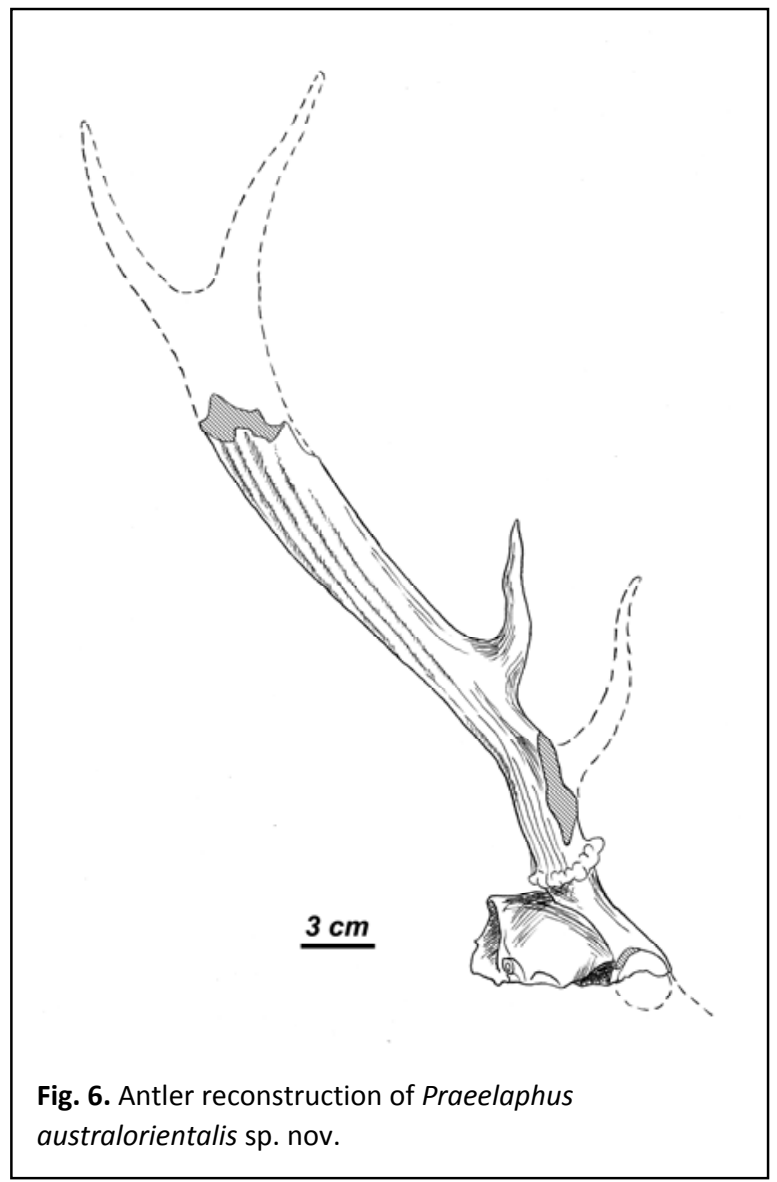

The index of relative braincase length (bregmaopisthocranion length to braincase breadth ratio) of Praeelaphus australorientalis amounts to $107.9 \%$ and is quite close to some fossil and Recent cervids (Metacervocerus rhenanus, Cervus nestii, Cervus elaphus) and modern Muntiacus muntjac and Muntiacus reevesi (Table 2). The antlered braincase IGF1378 (Fig. 10) of Praeelaphus cf. lyra from Olivola (Italy) is characterized by the same value of braincase shape index (107.9\%). The braincase of Praeelaphus australorientalis is relatively shorter and broader than in Axis axis, Rucervus duvaucelii, Panolia eldi, and the mean values of modern Dama dama (Table 2). According to the limited craniological material involved in the present comparative study, the bregma-opisthocranion length to braincase breadth ratio varies from 92.4 to $108.7 \%(n=8)$ in modern fallow deer males (the mean value is $98.2 \%$ ) and from 91.9 to $101.7 \%(n=5)$ in females (the mean values amounts to $97.6 \%$, practically equal to the index obtained for males). The small sample $(n=4)$ of Axis axis crania (variation range from 94.0 to $101.5 \%$, with mean value $97.6 \%$ ) suggests a braincase shape index similar to Dama dama. The single available skulls of Elaphurus davidianus, Rucervus duvaucelii and Panolia eldi are characterized by a braincase index lower than the ratio obtained for Praeelaphus australorientalis and the mean values of Dama dama and Axis axis. Regarding the relative breadth of the frontal bones with respect to overall braincase breadth, Praeelaphus australorientalis is characterized by a ratio (80.2\%), which is quite close to Elaphurus davidianus $(80.3 \%, n=1)$, Cervus nippon $(80.1 \%, n=1)$, Dama dama $(74.1-87.6 \%, \mathrm{n}=8)$, and Metacervocerus rhenanus $(75.4-88.9 \%, \mathrm{n}=4)$. As far as the craniological material involved in the present study is concerned, the studied cervids do not show any significant correlation between the relative frontal breadth on one hand and body size (the considered range of body size is from Muntiacus muntjak to Cervus elaphus), antler size or phylogenetic relationships on the other hand. The frontal breadth in Praeelaphus warthae is relatively larger than in Praeelaphus australorientalis: its braincase breadth reaches only $73.7 \%$ of the frontal breadth in a young male individual (measured from the type specimen of Praeelaphus warthae Nr. 1 from Weze-1).

The shape of the occiput (the ratio between occiput height and occiput width) in small/medium-sized cervids varies insignificantly and is quite similar in cervines with various relative antler size and weight: the index of occiput shape amounts to $63.8 \%$ in males of Dama dama with relatively large palmed antlers; this value is quite close to the index obtained for Hyelaphus porcinus with small three pointed antlers $(61.4 \%$, $\mathrm{n}=3$ ). The index of occiput shape in Praeelaphus australorientalis (64.8\%) falls within the variation of both Dama dama and Hyelaphus porcinus, and is significantly lower than in Praeelaphus warthae from Weze-1 


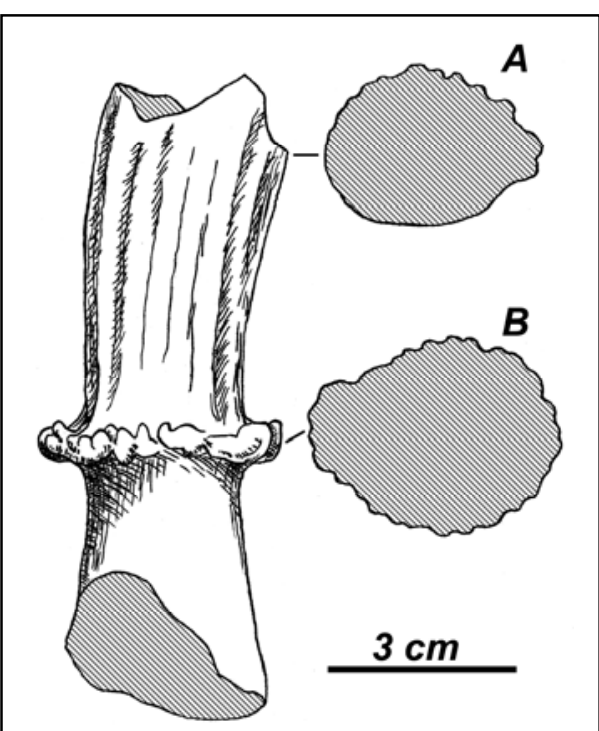

Fig. 7. Fragment of left antler with pedicle of Praeelaphus australorientalis sp. nov. from Berești (Romania); posterior view and transversal sections of proximal part of antler (A) and burr (B).
(77.0\%; the cranial fragment Nr. 362). Therefore, the shape of the neurocranium of Praeelaphus australorientalis seems comparatively short, broad and stands close to the modern Cervus, Muntiacus, and Late Villafranchian Metacervocerus. Its frontal bones are relatively narrow as in majority small/medium-sized and larger cervids.

The proximal antler fragment Nr. 231 from the Early Pliocene of Berești (Romania, curated at the Institute of Speleology of Bucharest) also belongs to Praeelaphus australorientalis (Fig. 7). The specimen preserved $69.0 \mathrm{~mm}$ of antler above the burr and does not show any sign of first ramification at this height. The pedicle is moderately long and somewhat compressed antero-posteriorly. The shape of the burr is irregular (LDM = $51.7 \mathrm{~mm}$; DAP $=43.6 \mathrm{~mm}$ ). The latero-medial diameter of antler at the level of breakage amounts to $41.5 \mathrm{~mm}$; the anteroposterior diameter at the same level amounts to $31.2 \mathrm{~mm}$.

\section{Discussion}

\subsection{Praeelaphus australorientalis vs. "Pliocervus kutchurganicus"}

The discussion of Praeelaphus australorientalis requires a comparison with the so-called "Pliocervus kutchurganicus" KOROTKEVICH, 1965, which was also reported from the Kuchurgan deposits. The latter species was based on poor fragments of antlers, while its dentition and cranial remains are unknown (KOROTKEVICH 1970). The type specimen of KOROTKEVICH's "Pliocervus kutchurganicus" is a proximal fragment of a comparatively stout shed antler (KOROTKEVICH 1970: fig. 44). In our opinion (CROITOR \& STEFANIAK 2009), this is a fully developed adult antler of Procapreolus moldavicus, since it falls within the variation range of antlers of this species from the Early Pliocene site of Weze Cave (Poland). Unlike the antlers from Velikoploskoe, the type specimen of "Pliocervus kutchurganicus" is still relatively thin (DAP of the antler above the burr is $29.2 \mathrm{~mm}$; DLM of the antler above the burr amounts to $31.2 \mathrm{~mm}$ ), the basal segment of the antler is undulated ("S-shaped" according to KOROTKEVICH 1970), deviating backward from the burr plane and then gently bending and inclining vertically. The anterior side of the basal segment of the antler of "Pliocervus kutchurganicus" bears a distinctive deep grove, which is often present in Procapreolus moldavicus but is missing in Praeelaphus australorientalis.

\subsection{Position within the genus Praeelaphus}

Praeelaphus australorientalis is a rather small-sized cervid of the subfamily Cervinae with an estimated body mass (based on occipital height) of $67 \mathrm{~kg}$. The body mass of the deer from Velikoploskoe places it close to the eco-evolutionary type of smaller Villafranchian "Dama-like" deer. P. australorientalis is the smallest species of the genus. The mean estimated body mass of $P$. perrieri is ca. $180 \mathrm{~kg}$, and that of $P$. warthae $120 \mathrm{~kg}$. The body mass of the largest male individual of $P$. warthae attained ca. $140 \mathrm{~kg}$ (CROITOR \& STEFANIAK 2009; CROITOR 2014). Apparently, $P$. warthae and $P$. perrieri show an increase of body size in the warthaeperrieri lineage during Ruscinian and Early Villafranchian.

Despite its comparatively small body size and such primitive characters as relatively long, sloped backward and little divergent pedicles, $P$. australorientalis possesses highly specialized and relatively robust 


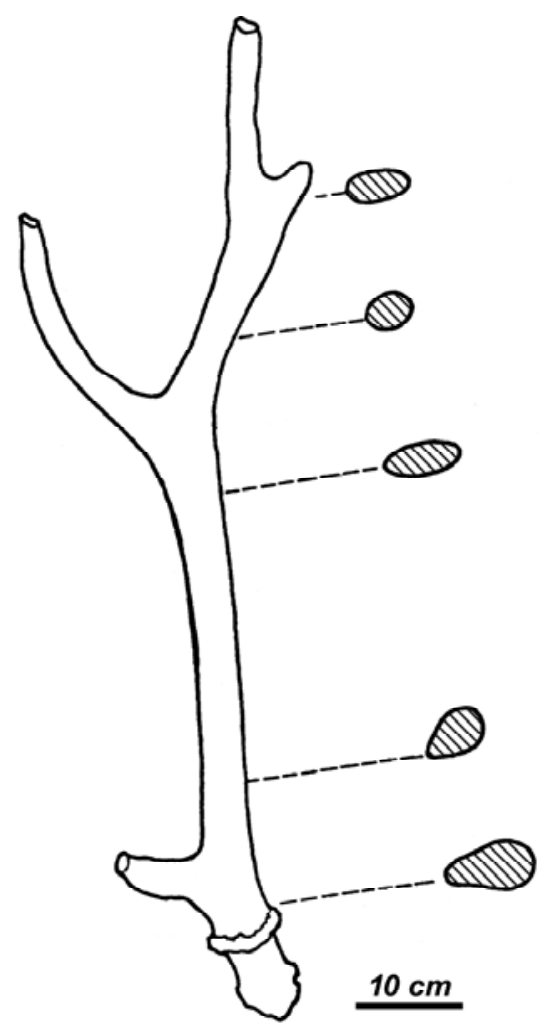

Fig. 8. Neotype of Praeelaphus perrieri (CROIZET \& JOBERT, 1828) from Etouaires (France). Adapted from HeINTZ (1970).

specific for Praeelaphus. Its braincase is slightly flexed and relatively short as in Praeelaphus australorientalis (the ratio bregma-opisthocranion length to neurocranium breadth amounts to $107.9 \%$ ), the parietal bones are slightly convex, the pedicles are moderately long, slightly compressed anteroposteriorly and somewhat inclined backward. The basioccipitale is bell-shaped, broadened in the pharyngeal tuberosities (Fig. 10C) as in P. australorientalis and P. warthae (CROITOR \& STEFANIAK 2009: fig. 18C). The preserved left bulla tympani (Fig. $10 \mathrm{C}$ ) is moderately large, smooth and rounded as in $P$. warthae (CROITOR \& STEFANIAK 2009). Although the first tine is not preserved, one can observe that the first ramification is situated rather high above the burr, though not as high as in P. australorientalis (Table 1). The antler base is regularly circular, however, the antler forms a peculiar anteroposterior extension below the first ramification. The antler beam is cylindrical above the first ramification and extends anteroposteriorly below the second ramification. The side surfaces of the antler are concave in the area of the second ramification. The second tine is somewhat compressed anteroposteriorly, set in the perpendicular plane with respect to the flattened portion of the antler beam and is situated at a long distance from the first tine, much longer than in P. australorientalis. The antler beam above the second tine is strongly compressed in the anteroposterior direction and gradually becomes broadened distally. The distalmost part of the antler is not preserved. The perpendicular orientation of the second antler ramification with respect to the plane of the flattened distal part of beam is a variable character in the sample from Olivola. The distal fragment of antler IGF1557 (Fig. 11) is characterized by a rather robust cylinder-shaped second tine situated in the plane of the beam blade-like extension. The posterior tine of 


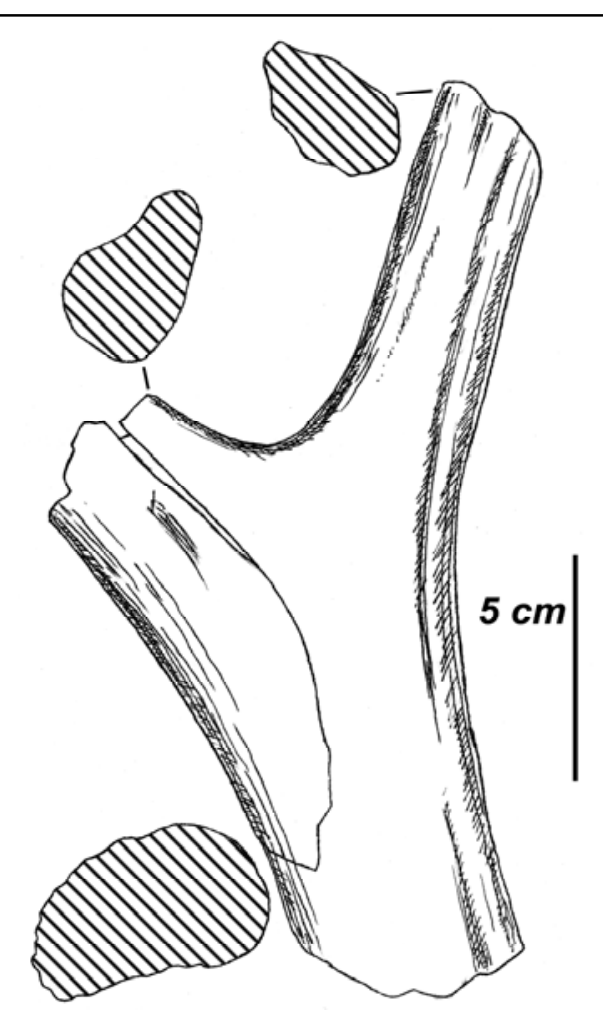

Fig. 9. Fragment of right antler PET1038 of Praeelaphus perrieri (CROIZET \& JOBERT, 1828) from Perrier-Etouaires (France) showing flattened antler beam in the area of the second ramification and the perpendicular orientation of the plane of the antler beam above the second ramification with respect to the second tine.

the distal bifurcation is more robust than the anterior one. The distance between ramifications in the specimen from Olivola is much shorter than in $P$. australorientalis and amounts to $184 \mathrm{~mm}$. Apparently, Praeelaphus from Olivola underwent a secondary body size reduction. Possibly, Praeelaphus from Olivola represents a true separate species, however, this question requires a detailed study, since the fauna from Olivola contains another small-sized cervid Cervus nestii that does not evolve the distal blade-like extensions of the antler beam (CROITOR 2014), while Praeelaphus lyra from Ponte a Elsa is still imperfectly known. Some fragmented remains of small-sized deer from the site of Monte Riccio, somewhat older than Olivola, were also ascribed to $P$. lyra (CROITOR 2012). It seems that the southern lineage of Praeelaphus represented by Early Villafranchian Praeelaphus lyra from Ponte a Elsa and P. cf. lyra from the Late Villafranchian of Olivola survived on the Italian peninsula until the Pachycrocuta brevirostris Event sensu MARTINEZ-NAVARRO (2010) (also known as the "wolf event": AZZAROLI 1983) and went extinct just before the dispersal of the first primitive Dama eurygonos with simple four-tined antlers in the Tasso F. U. (CROITOR 2006). The presence of Praeelaphus in the Early Pleistocene of the Italian Peninsula most probably has a refugial character. Possibly, Praeelaphus also survived in the Transcaucasian refugium; at least some cervid remains from the Early Pleistocene fauna of Dmanisi (Georgia) may be ascribed to this genus. VEKUA (1995: table 40) briefly described and figured a curious fragment of (right?) antler with a frontally oriented distal flattened portion ending in two tines, a perpendicularly oriented tine with proximal position with respect to the flattened portion of antler, and another still more proximal tine, which seems to be set on the medial side of the antler beam (Fig. 12). This specimen was described by VEKUA (1995) as Cervus (ex gr. Arvernoceros ardei). It is difficult to give an interpretation to the most proximal antler tine judging from the figure (is it a basal tine or an accessory second tine?). There is also a possibility that the reconstruction of the specimen is not exact, however, its affinity with more ancient European Praeelaphus seems to be quite plausible.

\subsection{Position within the subfamily Cervinae}

VISLOBOKOVA (1990) regards the relative length of the braincase relative to the total cranial length (and in particular, to the length of splanchnocranium) as an important character of cervid evolutionary specialization. According to VISLOBOKOVA (1990), the relatively short braincase with broadened occiput is an advanced character, which evolved in parallel in all main cervid lineages and is correlated with main evolutionary trends of cervids: increase of body size, increase of antler size, and adaptation to more coarse and fibrous forage. Since the relative length of the braincase hardly depends on ontogenetic stage of development and on sexual dimorphism in adults (MYSTKOWSKA 1966), this character requires attention here. The studied cranial proportions of modern and fossil small/medium-sized cervids do not provide a simple and clear phylogenetic or morpho-functional pattern (Table 2). 


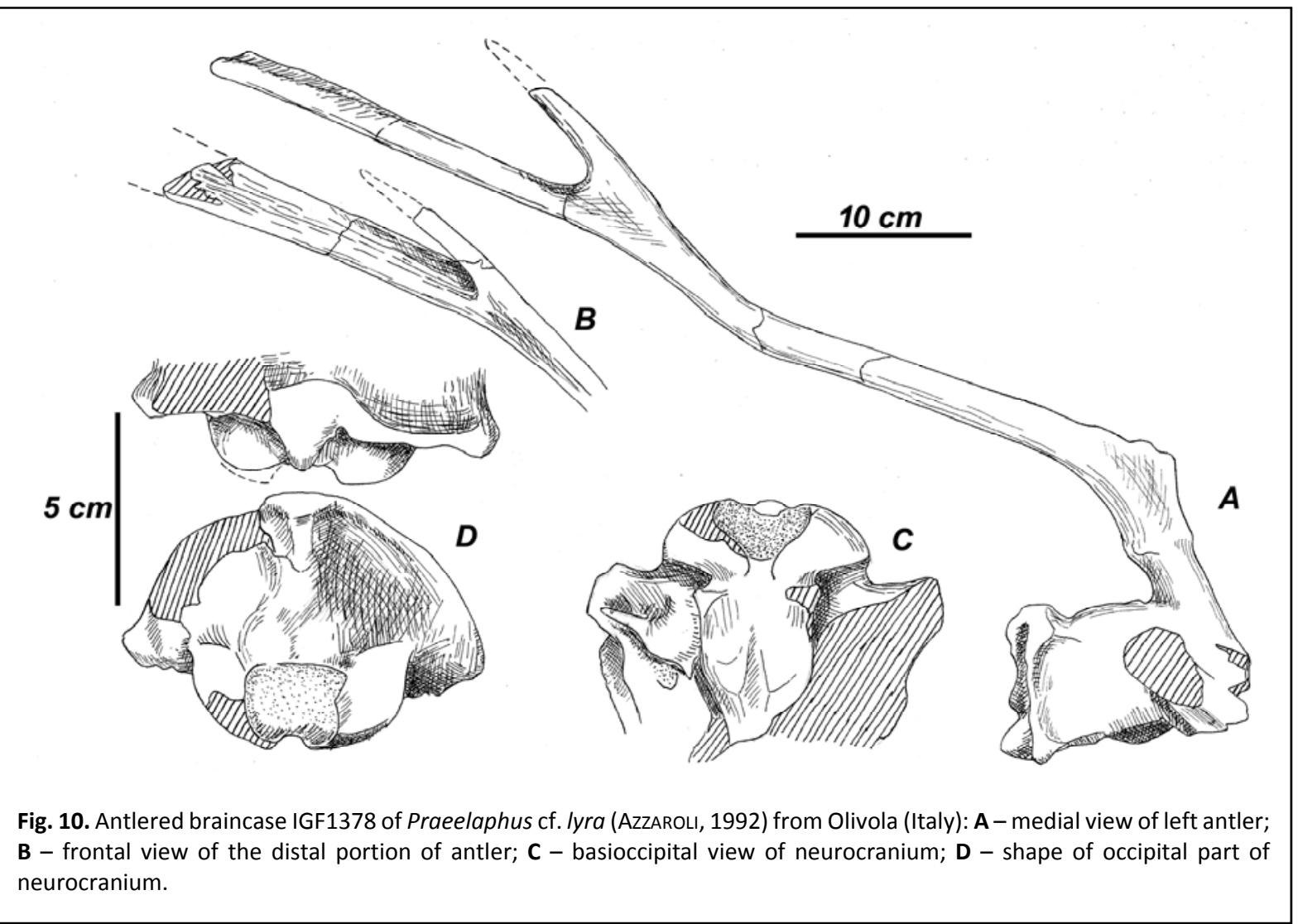

The phylogenetic and taxonomic significance of other basicranial characters (the shape and size of the foramen ovale, the shape and size of the bullae tympani, the length of the auditory tube) is quite variable among modern and fossil cervids. Although those characteristics have been used for taxonomical definitions at species and genus level within the subfamily Cervinae (POCOCK 1943; FLEROV 1952; SOKOLOV 1959), their potential for phylogenetic studies seems at the moment quite limited: the inflated and rounded bullae tympani are shared by Cervus nippon, Dama dama, Hyelaphus porcinus, and Metacervocerus rhenanus, while small, irregularly shaped tympanic bullae are characteristic of Muntiacus muntjak, Axis axis, Cervus elaphus, and Praeelaphus australorientalis (POCOCK 1943; FLEROV 1952; SOKOLOV 1959; VISLOBOKOVA 1990; CROITOR 2014, this study). Taking into account the genetic studies of PITRA et al. (2004) and GILBERT et al. (2006), the variation of shape and size of the bullae tympani among Cervinae does not fit the genetically supported phylogenetic model, although the small irregularly shaped bullae tympani and the short auditory tube are regarded as primitive morphological conditions (VISLOBOKOVA 1990).

It seems that the shape of the basioccipitale may have a clearer phylogenetic signature within plesiometacarpal Cervinae. The narrow V-shaped basioccipitale is characteristic of Cervus elaphus, but is also recorded in Panolia eldi, Rusa unicolor, Elaphurus davidianus (CROITOR 2014) and may be observed in the skull of Przewalskium albirostris figured by FLEROV (1952: fig. 40). The results of the genetic analyses of PITRA et al. (2004) and GILBERT et al. (2006) revealed that Cervus elaphus, together with Elaphurus davidianus, Przewalskium albirostris, Panolia eldi, and Rusa unicolor, forms a single phylogenetical stock, therefore, these authors propose to include the enlisted modern species into the genus Cervus sensu stricto. The V-shaped basioccipitale is also found in Muntiacus muntjak (the skull Nr. 780, osteological collection of "La Specola", Florence), suggesting a primitive condition of this character. PITRA et al. (2004) included also the hog deer Hyelaphus porcinus in the Cervus s. s. phylogenetic stock. The difficulty poses 


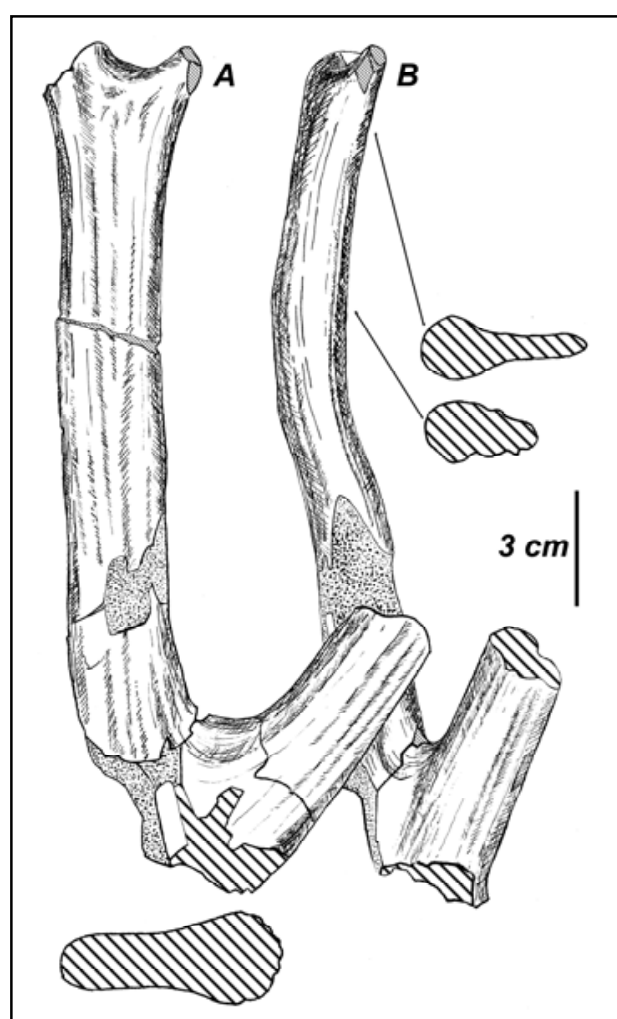

Fig. 11. Distal fragment of right antler IGF1557 of Praeelaphus cf. lyra (AzZAROLI, 1992) from Olivola (Italy): A - lateral view; B - frontal view.

the basioccipitale with broadened pharyngeal tuberosities in Hyelaphus porcinus (POCOCK 1943: fig. 7B). GILBERT et al. (2006) provided genetic and cariologic evidences that Hyelaphus porcinus is actually quite distant from the Cervus stock and stands closer to Axis axis. The broadened bellshaped (or U-shaped) basioccipitale of Hyelaphus porcinus is in accordance with the conclusions of GILBERT et al. (2006).

The broadened at pharyngeal tuberosities basioccipitale is shared by Praeelaphus australorientalis, $P$. warthae, and $P$. cf. lyra from Olivola, therefore, this archaic European lineage likely diverged very early from the Cervus s. s. phylogenetic branch. The same shape of basioccipitale is also recorded in Axis axis, Rucervus duvaucelii, and Dama dama, as well as in majority of extinct European genera, like Metacervocerus, Arvernoceros, Eucladoceros, Praemegaceros, and Megaloceros (CROITOR 2014). Genetic analysis has shown that in Axis axis and Rucervus duvaucelii split from the main stock of Cervinae very early (PITRA et al. 2004) and apparently represents the earliest radiation of Cervinae together with Praeelaphus, Arvernoceros, and Metacervocerus (CROITOR 2014). Unlike Dama, Praeelaphus australorientalis is characterized by small bullae tympani with irregular shape (an ancestral character) and relatively short and broader braincase (an advanced character). Actually, the relatively long braincase in Dama as estimated from the bregmaopisthocranion length may constitute a biased or/and ambiguous character. Dama is characterized by a much-flexed braincase, therefore the increased distance between bregma point and opisthocranion could be nothing more than a topographical correlation with the braincase flexion. On the other hand, the extreme braincase flexion in Dama relative to other Cervinae could be an adaptation to compensate for the elongated neurocranium in order to shorten the length of the lever between the atlanto-occipital articulation and the center of mass in order to increase the stability of the antlered head. However, this explanation is not fully satisfactory either, since the similarly elongated and narrow braincase in Megaloceros giganteus from Ireland (the index bregma-opisthocranion/braincase breadth in males varies from $85.4 \%$ to $93.3 \%$, the mean value is $89.7 \% ; n=7$ : CROITOR, work in progress) is less flexed than in fallow deer, while the relative antler size apparently is much more significant. In any case, the cranial morphology of Praeelaphus australorientalis and fallow deer represents two different and mutually exclusive directions of specialization.

The relative length of the braincase, the shape of the basioccipitale, and the relative length of pedicles approach Praeelaphus australorientalis to Metacervocerus rhenanus, however, the latter cervid is characterized by larger rounded bullae tympany and simple three-pointed antlers with a cylinder-shaped beam (its transversal section is regularly circular). In addition, the antlers of Praeelaphus australorientalis (even if we assume the specific advanced morphology of its antlers as a result of parallel evolution of closely related lineages) do not show morphological homology with antlers of Metacervocerus rhenanus or Metacervocerus pardinensis. The second tine in Praeelaphus australorientalis is situated very close to the first tine and does not look like an analogue of the distal bifurcation in Metacervocerus. Nonetheless, one cannot exclude a relatively close relationship between Praeelaphus and Metacervocerus resulting 


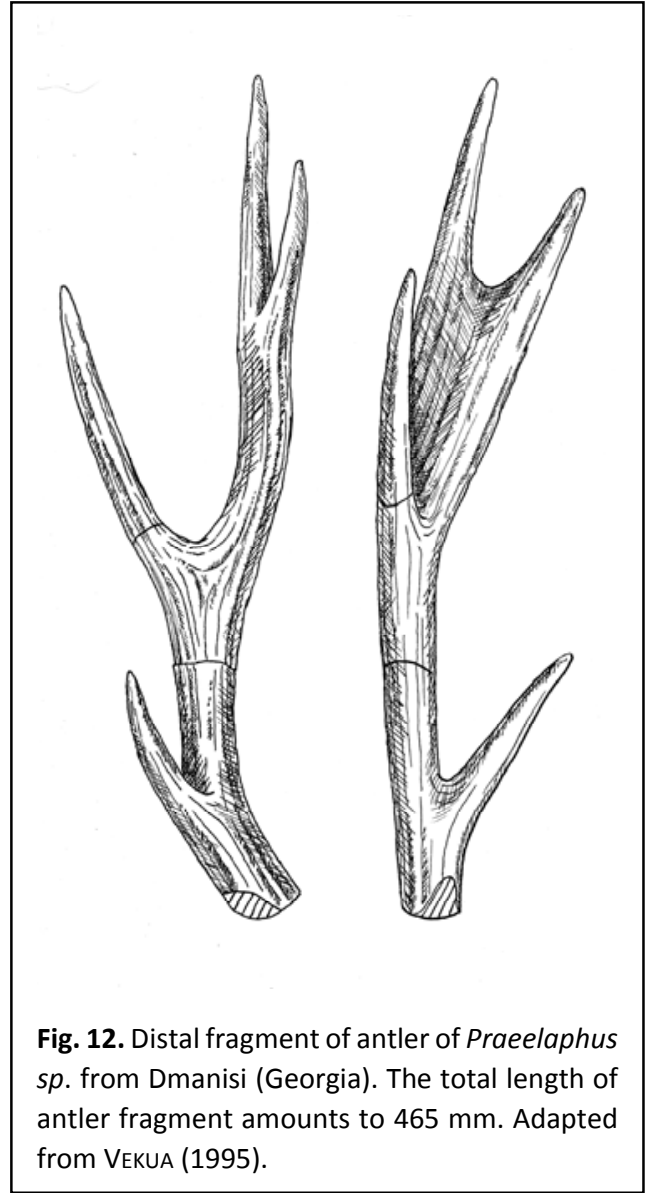

from the same evolutionary radiation event where the two genera may represent consecutive stages of evolutionary specialization of the antlers.

\subsection{Pliocene dispersals and palaeobiogeography of the subfamily Cervinae in western Eurasia}

Unlike the subfamily Capreolinae that represents an evolutionary radiation of telemetacarpal deer in the temperate latitudes of Eurasia, the subfamily Cervinae represents a southern Oriental radiation of plesiometacarpal deer. The Eastern part of the Oriental Zoogeographic Province is the area of the highest diversification of the subfamily Cervinae and the hypothetical center of the initial radiation of plesiometacarpal deer (GEIST 1998; DI STEFANO \& PETRONIO 2002; CROITOR 2014). The subfamily Cervinae in its modern understanding (including tribes Muntiacini and Cervini) proposed by GRUBB (2000) and confirmed by genetic studies (PITRA et al. 2004; GILBERT et al. 2006) represents a broad Late Neogene radiation from the most primitive Muntiacus and Elaphodus with simple antlers and large upper tusks to the larger Rucervus, which evolved complicated richly branched antlers (Rucervus schomburgki) and generally remains intact until the present days (GEIST 1988). The dispersal of Cervinae during the most part of Neogene was restricted in the eastern part of the Oriental Zoogeographic province, since the AlpineHimalayan mountain belt and the climate gradient toward the North created effective zoogeographic borders for the

Cervines (HEINTZ et al. 1990; CROITOR 2014). The Indian subcontinent, as well as Western Eurasia, were colonized by plesiometacarpal deer somewhat later, after some advanced evolutionary specializations were achieved.

An important, but still little studied biochronological event in Western Eurasia took place by the beginning of Early Pliocene: the dispersal of deer of the subfamily Cervinae during the Early Pliocene (CROITOR \& STEFANIAK 2009). The systematic composition of the family Cervidae of the Late Miocene of Western Eurasia is quite specific and very different from the systematic, evolutionary, and eco-morphological guise of Pliocene cervids. The Late Miocene deer of Western Eurasia are represented by the subfamily Capreolinae (genera Procapreolus, Cervavitus, Pliocervus) and a range of small-sized muntjac-like cervids, which, most probably, were direct descents of the local Miocene stem cervid radiation and survived until the early Late Pliocene (AZANZA et al. 2013; CROITOR 2014).

The small- to medium-sized European Procapreolus (or better to say, the "Procapreolus moldavicus group", since the genus Procapreolus in its current understanding proposed by KOROTKEVICH 1970 requires a thorough taxonomic revision; see CROITOR 2014) is a telemetacarpal cervid lineage with three-to-fivepointed antlers and with a typical for Capreolinae structure of the post-glenoid foramen (VALLI 2010). Pliocervus from the Late Miocene of France demonstrates a close affinity in antler, some cranial, and dental morphology with Pavlodaria orlovi described from the Hipparion fauna of Northern Kazakhstan, which is regarded by VISLOBOKOVA $(1980,1990)$ as the earliest representative of Capreolinae with choanae that are completely divided by the vomer (CROITOR 2014). Cervavitus was traditionally regarded as a 
transitional link between primitive muntjac-like deer and the "true deer" of the subfamily Cervinae (KHOMENKO 1913; FLEROV 1952; JANOVSKAYA 1954; KOROTKEVICH 1970; VISLOBOKOVA 1990). Unfortunately, the cranial morphology of Cervavitus from Eastern Europe is poorly known; the data on basicranial morphology are still missing. However, the basic "Capreolus-like" antler construction, relatively large premolars with advanced molarization of $\mathrm{P}_{4}$ and the presence of Palaeomeryx fold suggest that the betterknown species Cervavitus variabilis with palmed antlers is a good candidate for a forerunner of the modern telemetacarpal genus Alces, which is characterized by a vomer that is not completely divided by the choanae (CROITOR 2014).

The muntjac-like survivors from the Pliocene of Eastern Europe with simple two-tined antlers are ascribed to the Asian genera Eostyloceros and Muntiacus (CZYZEWSKA 1968; KOROTKEVICH 1970; VISLOBOKOVA 1990). The morphology of their antlers with a low position of the bifurcation of the beam and a long anterior tine rather reminds of Euprox from the Miocene of Europe. Both groups of archaic Capreolinae and muntjaclike cervids survived until the early Late Pliocene (CROITOR \& STEFANIAK 2009).

Croizetoceros is another cervid genus with an uncertain systematical position and poorly understood morphological affinities. This is a quite successful cervid group reported from the Late Miocene to Early Pleistocene of Western and Mediterranean Europe. HEINTZ (1970) described the best known Villafranchian species Croizetoceros ramosus (CROIZET \& JOBERT, 1828) from France, Italy, and Spain as a plesiometacarpal cervid with advanced dental morphology (P4 is molarized, Palaeomeryx fold is missing) and large antlers with multiple ramifications forming a comb-like crown. The earliest species of the genus, Croizetoceros pyrenaicus (DEPERET, 1890) with primitive unmolarized P4, is reported from the Late Miocene (MN13) of Spain (MORALES 1984). Another species, Croizetoceros proramosus, was described by DONG (1996) from the Early Pliocene of Southern France. The easternmost findings are reported from the Early Pleistocene of Greece (NMQ 18) as Croizetoceros ramosus gerakarensis KostOPOULOS, 1996 (KOSTOPOULOS \& ATHANASSIOU 2005). There are no remains of Croizetoceros or similar cervids found in Asia, therefore, this genus may have evolved from a local radiation of European muntjac-like stem cervids. Unfortunately, a detailed description of cranial morphology of Croizetoceros that could reveal its phylogenetic and systematic position is still missing. The antler and dental characters that are available for study do not demonstrate a direct relationship of Croizetoceros with any representative of the subfamily Cervinae (CROITOR 2014).

The overview of Late Miocene cervids from Western Eurasia demonstrates a remarkable absence of deer of the subfamily Cervinae. The first representatives of the subfamily Cervinae appear in Early Pliocene faunas of Eastern Europe and belong to three different genera with different degree of evolutionary specializations: Metacervocerus pardinensis, and Arvernoceros ardei. Apparently, the enlisted species represent the first important Late Miocene radiation of Cervinae, represented today by Axis axis and Rucervus duvaucelii from South-East Asia (PITRA et al. 2004).

The oldest remains of Metacervocerus pardinensis are from the Carbolia fluvial sediments of Brînza and Lucești, Moldova (MN15) (CROITOR 1997). This is a primitive Axis-like small deer with simple three-pointed antlers, relatively long pedicles, a primitive dental morphology with a cingulum in the upper molars, a relatively long lower premolar series, and a simple unmolarized $P_{4}$ (HEINTZ 1970). Apparently, the earliest (poor) remains of another cervine genus, Arvernoceros (Arvernoceros cf. ardei), are known from MN14 of Weze-1 (Poland) (CROITOR \& STEFANIAK 2009). This is a more specialized Rucervus-like medium-sized deer with rather long, obliquely set pedicles and a dental morphology that is quite similar to the previous species (HEINTZ 1970; CROITOR 2009). Arvernoceros ardei maintains a simple basic cervine antler bauplan; however, the distal ramification in large mature males is complicated with accessory tines and the development of a small palmation, while the basal tine bears an accessory prong (HEINTZ 1970). The third 
lineage of Cervinae is represented by the genus Praeelaphus, which still maintains a primitive dental morphology and some primitive cranial characteristics (such as rather long and obliquely set pedicles, a short orbito-frontal area, and short auditory tubes), however, is also characterized by an advanced, relatively shorter and broader braincase compared to modern Axis axis and Rucervus duvaucelii. The antlers of Praeelaphus are also quite advanced and specialized: they are four-pointed with an irregular ("pyriform") shape of the cross section of the beam, and a flattened distal portion of the beam (HEINTZ 1970; CROITOR 2012; CROITOR \& STEFANIAK 2009). The early representatives of the subfamily Cervinae coexisted in Europe with Late Miocene cervid holdovers, such as Procapreolus moldavicus, "Eostyloceros" pidoplitschkoi, and "Muntiacus" pliocaenicus/polonicus until the Early Villafranchian (CROITOR \& STEFANIAK 2009; FEJFAR et al. 2016).

\subsection{Dispersals and palaeobiogeography of the subfamily Cervinae in the Indian Subcontinent}

The western part of the Oriental Zooheographic province remained inaccessible for Cervidae until the Early Pleistocene, when the Old World deer could cross the Alpine-Hymalayan Mountain belt (HEINTZ et al. 1990). There are several poorly defined cervid forms found in the deposits of Siwalik Hills:

- "Cervus" triplidens LYDEKKER, 1876 is a medium-sized cervid (similar in body size to modern red deer) with comparatively high-crowned cheek teeth supplemented with a strong entostyle. The length of the upper molar row $\mathrm{M}^{1}-\mathrm{M}^{3}$ amounts to ca. $68.0 \mathrm{~mm}$ (measured from the figure in COLBERT 1935). Antlers are unknown. The stratigraphic provenance of this species is uncertain (Middle or Upper Siwaliks) (COLBERT 1935). Metacervocerus punjabiensis (BROWN, 1926) is another medium-sized deer (with an estimated body mass of ca. $200 \mathrm{~kg}$ ) with rather high-crowned cheek teeth and simple three-pointed antlers that, according to BROWN (1926) and CROITOR \& STEFANIAK (2009), remarkably remind Metacervocerus pardinensis (CROIZET \& JOBERT, 1928) from the Pliocene of Europe. BROWN (1926) indicated that the length of the upper molars attains $100 \mathrm{~mm}$; from the photo of the skull published in Brown's article (1926: figs. 2, 3) it is clear that this is a total length of the cheek tooth row $\mathrm{P}^{2}-\mathrm{M}^{3}$. Therefore, the dental measurements of Metacervocerus punjabiensis approach those of modern West European red deer Cervus elaphus ( $L \mathrm{P}^{2}-\mathrm{M}^{3}$ varies within 102.0 and $109.8 \mathrm{~mm}$ in the sample of red deer skulls curated at the National Museum of Natural History in Paris). This deer is also similar to "Cervus" triplidens in body size and hypsodont dentition. Therefore, the synonymy between Cervus punjabiensis BROWN, 1926 and Cervus triplidens LYDEKKER, 1876 is highly probable. It seems that "Cervus" triplidens and Metacervocerus punjabiensis represent the similar to modern Rusa unicolor eco-evolutionary type; however, the available distinguishing characters (the highcrowned cheek teeth in Siwalik cervids and the longer posterior antler tine of the distal bifurcation that rather represents a continuation of the antler beam, unlike the antlers in Rusa unicolor) do not allow to assume their direct ancestral relationship with modern sambar deer. GHAFFAR et al. (2011) included Brown's species in the genus Axis. However, the antler construction of the fossil deer under discussion is quite different: in modern Axis axis, the anterior tine of the distal antler fork is stronger and represents a continuation of beam (the morphological condition that is also seen in Rusa unicolor), while the posterior tine is more thin and short and represents an off-shot on the posterior side of the antler beam (LYDEKKER 1915: fig. 14). TeILHARD DE CHARDIN \& PIVETEAU (1930) termed this type of antler the "aristotelis type". The antler of Metacervocerus punjabiensis is different: the posterior tine of the distal fork is longer and represents a continuation of the antler beam, while the anterior tine of the fork is smaller and inserted on the anterior side of the antler beam. This is the so-called "hippelaphus type" of antler described by TEILHARD DE CHARDIN \& PIVETEAU (1930). The evolutionary and taxonomical significance of these two types of threepointed antlers are unclear, but they may theoretically represent two different evolutionary pathways of development of three-pointed antlers. 
- Rucervus sivalensis (LYDEKKER, 1880) is another medium-sized deer, based on a single isolated molar with a small lingual cingulum. LYDEKKER (1885) assumed its close relationship with modern Rucervus duvaucelii and included it in the arbitrary "Rucervine group". LYDEKKER (1885) also mentioned a cranium and antler fragments that show a certain resemblance to modern Rucervus. This material is discussed in more details by AZZAROLI (1954). FLEROV (1952) regarded this cervid form as Rusa sivalensis. COLBERT (1935) confirms the resemblance of antlers and skull Nr. 19829 (American Museum of Natural History) of "Cervus" sivalensis with Rucervus duvaucelii. The length of the lower molar series $\mathrm{M}_{1}-\mathrm{M}_{3}$ amounts to $78.0 \mathrm{~mm}$ (COLBERT 1935), representing an intermediary value between the range of lower molar series length of Praeelaphus perrieri/Arvernoceros ardei from the Early Villafranchian of Perrier, France (68.4-72.8 $\mathrm{mm}, \mathrm{n}=5$ ) and Arvernoceros sp. from Livenzovka, South Russia (Nr. 1810/3 - 90.0 mm; Nr. KП-1785/144 - 87.7 mm; Nr. MK-1419/2 - $91.9 \mathrm{~mm}$; curated at the Rostov-upon-Don State University). The antler is heavily build, with a round cross-section; its crown is formed by at least three crown tines inserted on the posterior side of the distal part of the beam (COLBERT 1935: fig. 146) as in modern Rucervus duvaucelii. The estimated body mass attains ca. $230 \mathrm{~kg}$.

- "Cervus" colberti AzZARol, 1954 is based on the damaged skull Nr. 19829 (AMNH). It shares with Rucervus sivalensis the presence of a weak lingual cingulum in the upper molars, but is somewhat larger. The length of the upper molar series amounts to ca. $82.0 \mathrm{~mm}$ (measured from COLBERT 1935: fig. 145), approaching to the size of European Praemegaceros obscurus from Pietrafitta, Italy (IGF4024) and the lower range of size variation of Megaloceros giganteus ( $\mathrm{n}=11$ ). AzzAROLI (1954) distinguishes "Cervus" colberti from Rucervus sivalensis by its weaker cingulum and more rounded "inner crescents" (apparently, protocone and hypocone). The degree of cingulum expression may be an individually variable character, while the lingual outlines of protocone and hypocone depend of the stage of molar wear, which seems to be very advanced in the type specimen (COLBERT 1935: fig. 145). Therefore, there is a high probability that "Cervus" colberti AZZAROLI, 1954 is an advanced form closely related to Rucervus sivalensis (LYDEKKER, 1880). The estimated body mass amounts to ca. $360 \mathrm{~kg}$. Another large-sized species, Cervus latidens LYDEKKER, 1876, was described on the basis of some isolated molars that rivalled Megaloceros giganteus in the size. Later, LYDEKKER (1885) tentatively included C. latidens in the bovid genus Oreas, and therefore this species is excluded from the present discussion.

- Rucervus simplicidens (LYDEKKER, 1876) differs from the previous species mostly by the absence of a cingulum in the molars and more hypsodont teeth. The stratigraphic provenance of this species is also doubtful (Middle or Upper Siwaliks: Colbert 1935; Azzaroli 1954). Azzaroli (1954) included this species in the genus Rucervus, while the cranium BM39570 was reported as Rucervus cf. simplicidens. The morphological characters of the cranium BM39570 that are available for observation (small upper canines; large ethmoidal openings with a long border formed by the nasal bones at more than $1 / 2$ of ethmoidal opening length; position of the anterior edges of the orbits above the posterior edge of $\mathrm{M}^{3}$ ) approach it to modern Rucervus duvaucelii. Unlike modern barasingha deer, Rucervus from the Siwaliks is characterized by short nasal bones that do not reach the line connecting the anterior edges of the orbits (an ancestral character), and smaller preorbital pit (an advanced specialization). The estimated body mass attained 170 $\mathrm{kg}$. Some antler fragments from the Siwalik sample (one of the specimens is attached to a long pedicle) were ascribed to Rucervus sp. I and Rucervus sp. II (AzZAROLI 1954). According to AzZAROLI (1954: fig. 7), the antler ascribed to Rucervus sp. II with long cylindrical pedicle, high insertion of the first tine and gentle curvature of the beam above the first bifurcation most probably belongs to Rucervus simplicidens.

- It is necessary also to indicate the presence of Panolia sp. (= Rucervus sp. I: AzZAROLI 1954: fig. 6) in the Siwalik fauna. The antlers of Rucervus sp. I (BM41834b, BM41834c, 41834d) are characterized by a comparatively low position of the first tine, a very obtuse angle of the first ramification, a strong backward 
bending of the beam at the level of the first ramification, the occasional presence of accessory prongs above the first ramification, and a small distal bifurcation (AzZAROLI 1954: fig. 6). As AzzAROLI (1954) reasonably noticed, the enlisted characters correspond to the modern Panolia eldi, which is part of the Cervus elaphus evoluionary stock (PITRA et al. 2004). AzZAROLI (1954) also reported from the Siwaliks a quite large-sized cervid similar to Eucladoceros (Euctenoceros [?] sp. fide AzZAROLI 1954: fig. 7a) that is represented by a proximal fragment of a shed antler characterized by a high insertion of the basal tine and two accessory prongs just above the basal ramification. Actually, the accessory prongs in the area of the first ramification are common in Panolia eldi, which, as it is said above, is also present in the deposits of Siwalik Hills. Therefore, the attribution of the "Eucladoceros-like" antler to Panolia sp. seems to be most plausible.

- "Cervus" rewati ARIF et al., 1992 is the smallest Siwalik cervid (equaling in size to chital and fallow deer) described from Plio-Pleistocene deposits of Rajwal (Upper Siwaliks). Only dental remains of this deer are known so far: the length of the lower molar series amounts to $50.2 \mathrm{~mm}, \mathrm{P}_{4}$ is primitive and unmolarized. The molar measurements are close to those of modern chital Axis axis (ARIF et al. 1992). However, "Cervus" rewati differs from Axis axis in having stronger ectostylids and anterior enamel folds in the lower molars. The body size of "Cervus" rewati approaches that of the so-called "Dama-like" deer from the Pliocene and Early Pleistocene of Europe. The estimated body mass attains ca. $60 \mathrm{~kg}$. GHAFFAR et al. (2011) reported dental remains of a similarly small-sized cervid "Cervus" cf. rewati from the Dhok Pathan Formation of the Middle Siwaliks, suggesting the Early Pliocene age of the first cervids that dispersed into the Indian subcontinent. However, BIBI \& METAIS (2016) doubted the early occurrence of Cervidae south of the AlpineHimalayan mountain belt, noticing that the very fragmentary dental remains described by GHAFFAR et al. (2011) appear to belong to bovids.

The overview of the first Cervines from Eastern Europe and Indian Subcontinent revealed some interesting facts: I) both palaeozoogeographic areas yielded closely related counterpart cervid forms that represent the earliest important evolutionary radiation of Cervinae (Metacervocerus pardinensis and Metacervocerus punjabiensis; Arvernoceros ardei and Rucervus sivalensis); II) despite the vast variation range of body size in the first cervines from Eastern Europe and the Indian Subcontinent, the smallest cervids attain the estimated body mass of ca. $60 \mathrm{~kg}$ (Praeelaphus australorientalis and "Cervus" rewati). Therefore, one can assume that the dispersal potential in deer of the subfamily Cervidae during the Pliocene epoch increased when the $60 \mathrm{~kg}$ threshold of body mass was surpassed. This assumption may explain why the smallest cervid forms that arrived during the Plio-Pleistocene in Western Eurasia always represent the so-called "Dama-like" body size class interpreted by Azzarol (1992) as a single genus Pseudodama.

The palaeontological record from China is crucial for the understanding of the Cervinae evolution and dispersal events. The first comparatively larger cervids with three-pointed antlers in China are recorded at the beginning of the Baodean age (ca. $7 \mathrm{Ma}$ ) and usually are ascribed to the genus Cervavitus (WANG \& ZHANG 2014). Nonetheless, the belonging of those archaic medium-sized deer to Cervavitus from the Late Miocene of Eastern Europe is doubtful and some of the Chinese Late Neogene cervid forms may be reasonably considered as the most ancient representatives of Cervinae (CZYŻEWSKA 1968; DI STEFANO \& PETRONIO 2002). Teeth, mandibles, and antlered frontlets from Late Miocene of Lantian (Shaanxi Province, China) described by WANG \& ZHANG (2014) as "Cervavitus novorossiae" belong to rather medium-sized cervids (possibly, more than one species) with three-tined antlers, moderately long to very long pedicles ( $L=D ; L>D)$ and conspicuously primitive dentition: $P_{4}$ is not molarized, Palaeomeryx fold is missing (unlike Cervavitus from Eastern Europe), the accessory enamel fold of protocone in upper molars figured by WANG \& ZHANG (2014: fig. 2A) is not present (unlike European Late Miocene Capreolinae, including Cervavitus: 
CROITOR 2014), the premolar/molar ratio in three most complete specimens amounts to $70.2 \%, 74.1 \%$, and $62.4 \%$ indicating relatively long premolar series. The estimated body mass based on dental remains from Lantian varies between 65 and $115 \mathrm{~kg}$. "Cervavitus" shanxius DoNG \& HU, 1994 from Late Miocene - Early Pliocene site Hounao (Sanxi Province, China) is characterized by a primitive dentition lacking the Palaeomeryx fold and possessing rather large upper canines and holometacarpal limbs. The estimated body mass of "Cervavitus" shanxius based on mean dental measurements (DONG \& HU 1994) attained ca. $75 \mathrm{~kg}$. Therefore, the first cervids of the fallow deer body size class appeared in China shortly before Praeelaphus australorientalis dispersed into Western Eurasia.

Metacervocerus species from Europe and the Indian Subcontinent maintained a similarly primitive threepointed antler construction, however, they developed adaptations to different ecological niches: European Metacervocerus ( $M$. pardinensis, $M$. rhenanus) maintained initial eco-morphological adaptations (small body size, primitive and brachyodont dentition) of a forest browsing dweller until the extinction of this lineage by the end of the Early Pleistocene. Metacervocerus punjabiensis (= "Cervus" triplidens?) evolved into a larger cervid form with simple antlers (eco-morphologically similar to the modern Rusa unicolor) and hypsodont dentition, probably occupying the ecological niche of a large-sized savannahwoodland mixed feeder/grazer.

Three other Siwalik cervid species (Rucervus sivalensis, Rucervus simplicidens, and "Cervus" colberti), apparently represent a local evolution of Rucervus. This genus shares essentially the same bauplan of antler with Arvernoceros from the Pliocene and the Early Pleistocene of Western Eurasia (CROITOR 2009, 2014). It is important to notice that Rucervus sivalensis also possesses a lingual cingulum in the upper molars as Arvernoceros ardei from the Early Villafranchian of France, thus suggesting a close relationship (possibly congeneric) between those two species. The lack of satisfactory cranial material does not allow at the moment to synonymize Arvernoceros and Rucervus. The evolution of Siwalik Rucervus advanced in two directions and resulted in a smaller Rucervus simplicidens with a more specialized and high-crowned dentition and a larger "Cervus" colberti, which maintained a primitive dentition and probably was a highlever browser. A large-sized cervid similar to "Cervus" colberti possibly dispersed via the Anatolian or Caucasian way to South-East Europe and stands at the basis of the lineage of Early Pleistocene Arvernoceros verestchagini reported from Greece and Moldova. Arvernoceros verestchagini was a very large (up to $700 \mathrm{~kg}$ ) long-limbed high-level browser with rather simple antlers, which was ecologically more or less similar to modern giraffes (CROITOR \& KOSTOPOULOS 2004).

It seems that the capacity for dispersal in Cervidae represents a certain evolutionary advantage related to the general eco-evolutionary specialization of a species. The Eurasian palaeontological record (see BIBI \& METAIS 2016 for an overview) shows that Moschidae is another ruminant family that failed to overcome the Alpine-Himalayan Mountain Belt. According to Flerov (1952), the modern Asian fauna contains three species of a single genus Moschus that dispersed northeast from the Himalayan Mountain Belt. Taking into account the fact that Moschidae were always only represented by rather small-sized (up to $15 \mathrm{~kg}$ in modern species: FLEROV 1952) cryptic antlerless forest dwellers, it may be a helpful key in understanding the significance of body mass in cervid success in colonizing the vast areas of the Indian Subcontinent, which remained inaccessible to moschids. The higher dispersal capacities in larger cervids is conditioned not only by the ability to overcome larger distances, but also by the larger home range and the higher ecological flexibility due to the increased range of diet including the low quality forage (MYSTERUD 1998). Of course, the large body size itself does not represent a sufficient condition enabling dispersal capacities in cervids, however, it opens a new adaptive zone for them. The possible correlation between body size and dispersal capacity in cervids suggests that the body size structure of herbivore guilds in faunas that 
resulted from dispersal events is also influenced by a certain body mass threshold that enhances the dispersal capacities of species and not necessarily reflects all available ecological niches.

The increased dispersal capacity of Early Pliocene Cervinae permitted not only to overcome immense distances until Western Eurasia, but also to pass the Himalayan Mountain Belt and to colonize the tropical areas of the Indian Subcontinent, which before were inaccessible to small-sized cervids. Muntiacus muntjak, the smallest deer of the Indian Subcontinent, represents a curious exception that needs some comments. Although the earliest representative of the genus, Muntiacus leilaoensis, is known already from the Late Miocene (ca. 7-9 Ma) of South-East China (DoNG et al. 2004), the dispersal of Muntiacus into the Indian Subcontinent seems to be a very late event dating back to the late Middle Pleistocene (MIS6), although a gap exists in the Indian palaeontological record between the Early Pleistocene of the Siwalik Hills and the late Middle Pleistocene of the Billasurgam cave complex (Southern India) where the earliest well-dated remains of muntjacs were discovered (ROBERTS et al. 2014). BISWAS \& SONAKIA (2001) also reported Muntiacus cf. muntjak from Middle Pleistocene deposits of the Nadmada River, Central India. Apparently, the explanation of late dispersal of Muntiacus into the Indian Subcontinent should be sought in the palaeogeography of Southeast Asia. Himalayan Mountains represent an obvious geographic obstacle for tiny tropical cervids. Nonetheless, although not so evident, the north-south extending IndoBurmese Ranges (1500-4000 m) also represent an unavoidable obstacle for tropical forest dwellers. The Indo-Burmese Ranges impede the passage of humid summer monsoonal winds from the southwest into central Myanmar, producing arid conditions in this area (BIBI \& METAIS 2016). At present, central Myanmar is a semi-arid zone with an annual precipitation of $600-1000 \mathrm{~mm}$ and a mean annual temperature of around $30^{\circ} \mathrm{C}$ (BENDER 1983). In contrast, the western and southern parts of Myanmar receive 3000-4000 $\mathrm{mm}$ of rainfall annually and are covered with tropical rainforests. At their northern extent, the IndoBurman Ranges are continuous with the Himalayan-Tibetan Plateau, thus closing the access to the Indian Subcontinent from the East. Apparently, the dispersal of Muntiacus into the Indian Subcontinent was possible during the glacial episodes that caused the sea level drop and the emergence of Sundaland, which was an easier path for Muntiacus dispersal, since it permitted to bypass the Indo-Burmese Ranges from the south.

\section{Conclusions}

Praeelaphus australorientalis sp. nov. is the earliest small-sized deer of the subfamily Cervinae recorded in Western Eurasia. The new species is characterized by advanced four-tined antlers with blade-like extensions of the distal part, relatively long and little divergent pedicles with narrow frontal bones, which represent an ancestral morphological condition, and a relatively short and broad braincase that is regarded here as an advanced character. The post-glenoid foramen is closed from the medial side by the bony bridge of squamosal bone, thus confirming the attribution of Praeelaphus australorientalis sp. nov. to the subfamily Cervinae. The broadened pharyngeal tuberosities basioccipitale at (U-shaped or "bell-shaped") suggests that this deer is quite distant from the Cervus elaphus phylogenetical stock and belongs to an earlier evolutionary radiation of plesiometacarpal deer represented today by the genera Axis and Rucervus. The attribution of the new species to the genus Praeelaphus is supported by the general antler bauplan and the presence of a specific blade-like flattening in the distal portion of the antler beam.

The comparative study of the earliest European Cervinae with the deer fauna from the Siwalik Hills revealed counterpart cervid species (Metacervocerus pardinensis and M. punjabiensis, respectively) and genera (Arvernoceros and Rucervus, respectively) suggesting that the cervid dispersal events in Western Eurasia and Indian Subcontinent follows the same evolutionary advancements in Cervinae. Those evolutionary advancements ensured the higher dispersal capacities permitting to overcome the large 
distances (in the case of Western Eurasia) and mountain obstacles (in the case of the Indian Subcontinent). The similar body size (ca. $60 \mathrm{~kg}$ ) of the first smallest plesiometacarpal deer in Europe Praeelaphus australorientalis and the smallest cervid from Siwalik Hills "Cervus" rewati possibly indicates the body size threshold enabling the higher dispersal capacities within the subfamily Cervinae. The higher dispersal capacities in large-sized cervids are related to larger home range and ecological opportunistic flexibility due to the increased dietary range including low quality fibrous forage. Muntiacus muntjak represents a single exception as a small-sized cervid in the modern fauna of the Indian Subcontinent. The most plausible explanation is that Muntiacus muntjak dispersed into the Indian Subcontinent via Sundaland that emerged during the Middle Pleistocene glaciations.

\section{Acknowledgements}

I am thankful to MiHAI URSU and THEODOR OBADA for their kind help and assistance while providing the access to the fossil material from the exposition of the National Museum of Ethnography and Natural History of Chisinau. Many thanks to AleXANDRA VAN DER GEeR and Dimitris S. Kostopoulos for their valuable comments and suggestions that improved the quality of the article.

\section{References}

ARIF, M., SHAH, S.M.I. \& DE VoS, J. (1992): Cervus rewati sp. nov. (Mammalia, Cervidae) from the Upper Siwaliks of Pakistan. - Memoirs of Geological Survey of Pakistan, 17: 11-23.

Azanza, B., Rössner, G.E. \& Ortiz-Jaureguizar, E. (2013): The early Turolian (late Miocene) Cervidae (Artiodactyla, Mammalia) from the fossil site of Dorn-Dürkheim 1 (Germany) and implications on the origin of crown cervids. - Palaeobiodiversity and Palaeoenvironments, 93 (2): 217-258.

AzzARol, A. (1947): I cervi fossili della Toscana con particolare riguardo alle specie villafranchiane. - Palaeontographia Italica, 43: 46-81.

AzzARol, A. (1954): Critical observations upon Siwalik Deer. - Proceedings of the Linnaean Society of London, 165: 75-

83.

Azzarol, A. (1983): Quaternary mammals and the "End-Villafranchian" dispersal event - a turning point in the history of Eurasia. - Palaeogeography, Palaeoclimatology, Palaeoecology, 44: 113-139.

Azzarol, A. (1992): The cervid genus Pseudodama n. g. in the Villafranchian of Tuscany. - Palaeontographia Italica, 79:

$1-41$.

BeNDER, F. (1983): Geology of Burma. - VIII + 295 pp.; Berlin, Stuttgart (Gebr. Borntraeger).

BiBI, F. \& MetAIS, G. (2016): Evolutionary History of the Large Herbivores of South and Southeast Asia (Indomalayan Realm). - In: AhreStANI, F.S. \& SANKARAN, M. (Eds.): The Ecology of Large Herbivores in South and Southeast Asia. - Ecological Studies, 225: 15-88.

BISWAS, S. \& SONAKIA, A. (2001): Some fossils of deer from Quaternary deposits of Madhia Pradesh, India. - Journal of the Palaeontological Society of India, 46: 43-49.

Bouvrain, G., GeraAds, D. \& Jehenne, Y. (1989): Nouvelles données relatives à la classification des Cervidae (Artiodactyla, Mammalia). - Zoologischer Anzeiger, 223: 82-90.

Brown, B. (1926): A new deer from the Siwaliks. - American Museum Novitates, 242: 1-6.

Colbert, E.H. (1935): Siwalik Mammals in the American Museum of Natural History. - Transactions of the American Philosophical Society, 26: 1-401.

CROITOR, R. (1997): Fossil remains of the deer of Pseudodama genus from Late Pliocene of Basarabia. - Buletinul Academiei de Științe a Republicii Moldova, Științe Biologice și Chimice, 2: 78-80.

CRolToR, R. (1999): On Systematic Position of "Moldavian sambar deer" from the Pliocene of Moldova. - Bollettino della Società Palaeontologica Italiana, 38 (1): 87-96.

CROITOR, R. (2006): Early Pleistocene small-sized deer of Europe. - Hellenic Journal of Geosciences, 41: 89-117.

CROITOR, R. (2009): Systematical position and evolution of the genus Arvernoceros (Cervidae, Mammalia) from PlioPleistocene of Eurasia. - Oltenia. Studii şi comunicări. Ştiinţele Naturii, 25: 375-382.

CROITOR, R. (2012): Lower Pleistocene ruminants from Monte-Riccio (Tarquinia, Italy). - Oltenia. Studii şi comunicări, Ştiinţele Naturii, 28: 221-226.

CROITOR, R. (2014): Deer from Late Miocene to Pleistocene of Western Palearctic: matching fossil record and molecular phylogeny data. - Zitteliana, (B), 32: 115-153. 
CRoitor, R. \& Kostopoulos, D.S. (2004): On the systematic position of the large-sized deer from Apollonia, Early Pleistocene, Greece. - Paläontologische Zeitschrift, 78 (1): 137-159.

CRoItor, R. \& StefANIAK, K. (2009): Early Pliocene deer of Central and Eastern European regions and inferred phylogenetic relationships. - Palaeontographica, (A), 287: 1-39.

Croizet, J.B. \& Jobert, A.C.G. (1828): Recherches sur les ossements fossiles du département du Puy-de-Dôme. - 225 pp.;

Paris.

CZYżEWSKA, T. (1968): Deer from Węże and their relationship with the Pliocene and Recent Eurasiatic Cervidae. - Acta Palaeontologica Polonica, 13 (4): 537-593.

DiStefano, G. \& Petronio, C. (2002): Systematics and evolution of the Eurasian Plio-Pleistocene tribe Cervini (Artiodactyla, Mammalia). - Geologica Romana, 36: 311-334.

DonG, W. (1996): Les Cervidés (Artiodactyla) rusciniens (Pliocène) du Languedoc et du Roussillon (France). - Bulletin du Muséum National d'Histoire Naturelle, (C), 18: 133-163.

(3): 209-227.

Dong, W. \& HU, C.K. (1994): The Late Miocene Cervidae from Hounao, Yushe Basin, Shanxi. - Vertebrata PalAsiatica, 32

DonG, W., PAN, Y. \& LIU, J. (2004): The earliest Muntiacus (Artiodactyla, Mammalia) from the Late Miocene of Yuanmou, southwestern China. - Comptes Rendus Palevol, 3 (5): 379-386.

Fejfar, O., Heintz, É., ĎuRIŠovÁ, A. \& SABOL, M. (2016): Pliocene vertebrates from Ivanovce and Hajnáčka (Slovakia). X. Cervidae. - Neues Jahrbuch für Geologie und Paläontologie, Abhandlungen, 281 (1): 1-33.

FLerov, K.K. (1952): Musk deer and deer. - In: The Fauna of USSR, 1 (2): Mammals. - 256 pp.; Moscow \& Leningrad (Publishing House of the Academy of Sciences of USSR) [in Russian].

Ghaffar, A., Akhtar, M., Khan, M.A., Samiullah, K. \& Khan, A.M. (2011): Cervus cf. rewati (Cervidae, Mammalia) from the Pliocene Dhok Pathan Formation (Middle Siwaliks), Pakistan. - Austrian Journal of Earth Sciences, 104 (1): 107-113.

GrubB, P. (2000): Valid and invalid nomenclature of living and fossil deer, Cervidae. - Acta Theriologica, 45 (3): 289-307.

HEINTZ, E. (1970): Les cervides villafranchiens de France et d'Espagne. - Memoires du Museum national d'histoire naturelle, (C), 22 (1-2): 5-303 + 1-206.

Heintz, E., Brunet, M., Battall, B. \& Jehenne, Y. (1990): The main features of the cervid palaeobiogeography. Quartärpaläontologie, 8: 79-82.

JANIS, C.M. (1990): Correlation of cranial and dental variables with body size in ungulates and macropodoids. - In:

DAmUth, J. \& MACFAdDEN, B.J. (Eds.): Body size in Mammalian Paleobiology: Estimation and Biological Implications: 255-299; Cambridge (Cambridge University Press).

JANOVSKAYA, N.M. (1954): New deer from middle Pliocene of Moldavia. - Transactions of the Palaeontological Institute, 47: 163-171 [in Russian].

KHOMENKo, I. (1913): Meotian fauna of v. Tarakliya of Bendery district. 1. The ancestors of modern and fossil Cervinae. 2. Giraffidae and Cavicornia. - Annuaire géologique et minéralogique de la Russie, 15: 107-132 [in Russian].

KoRotKeVICH, E.L. (1970): Late Neogene deer of the north Black Sea area. - 175 pp.; Kiev (Naukova Dumka) [in Russian]. KOROTKEVICH, E.L. (1988): History of formation of Hipparion fauna in Eastern Europe. - 162 pp.: Kiev (Naukova Dumka) [in Russian].

Kostopoulos, D.S. \& Athanassiou, A. (2005): In the shadow of bovids: suids, cervids, and giraffids from the Plio-Pleistocene of Greece. Les ongulés holarctiques du Pliocène et du Pléistocène. - Quaternaire, 2 (hors-serie): 179-190.

LESSON, R.P. (1836): Histoire naturelle, générale et particulière des mammifères et des oiseaux. - 413 pp.; Paris (Pourrat frères).

LYDEKKER, R. (1885): Catalogue of the remains of Siwalik Vertebrata contained in the Geological Department of the Indian Museum, Calcutta. Part 1. Mammalia. - 115 pp.; Calcutta (Government Printing).

LYDEKKER, R. (1915): Catalogue of the ungulate mammals in the British Museum (Natural History). IV. Artiodactyla. - 438 pp.; London (William Gloves \& Sons).

Martínez-Navarro, B. (2010): Early Pleistocene faunas of Eurasia and hominid dispersals. - In: Fleagle, J.G., Shea, J.J., Grine, F.E., BAdEN, A.L. \& LEAKEY, R.E. (Eds.): Out of Africa I: The First Hominin Colonization of Eurasia. - Vertebrate Paleobiology and Paleoanthropology Series: 207-224; Dordrecht (Springer).

MoRAles, J. (1984): Venta del Moro: su macrofauna de mamiferos y biostratigrafia continental del Mioceno mediterraneo. - 340 pp.; Madrid (Universidad Computense).

Mysterud, A. (1998): The relative roles of body size and feeding type on activity time of temperate ruminants. Oecologia, 113: 442-446.

MYSTKOWSKA, E. (1966): Morphological variability of the skull and body weight of the Red Deer. - Acta Theriologica, 11 (5): $129-194$

Pevzner, M.A., Vangengeim, E.A., Vislobokova, I.A., Sotnikova, M.V. \& Tesakov, A.S. (1996): Ruscinian of the territory of the former Soviet Union. - Newsletters on Stratigraphy, 33 (2): 77-97.

Pitra, C., Fickel, J., MeijaArd, E. \& Groves, P.C. (2004): Evolution and phylogeny of old world deer. - Molecular Phylogenetics and Evolution, 33: 880-895. 
Pocock, R.I. (1943): The larger deer of British India. Part IV: the Chital Axis and Hog-Deer Hyelaphus. - Journal of the Bombay Natural History Society, 44: 169-178.

Pomel, M. (1853): Catalogue méthodique et descriptif des vertébrés fossiles découverts dans le bassin hydrographique supérieur de la Loire. - 193 pp.; Paris (Baillière).

Roberts, P., Delson, E., Miracle, P., Ditchfield, P., Roberts R.G., Jacobs, Z., Blinkhorn, J., Clochon, R.L., Fleagle, J.G., Frost, S.R., Gilbert, C.C., GunnelL, G.F., Harrison, T., Korisettar, R. \& Petraglia, M.D. (2014): Continuity of mammalian fauna over the last 200,000 y in the Indian subcontinent. - Proceedings of the National Academy of Sciences, 111 (16): 5848-5853.

Teilhard de Chardin, P. \& Piveteau, J. (1930): Les mammifères fossiles de Nihovan (Chine). - Annales de Paléontologie, 19:

$5-132$.

VALLI, A. (2010): Dispersion of the genus Procapreolus and the relationships between Procapreolus cusanus and the roe deer (Capreolus). - Quaternary International, 212: 80-85.

VAngengeim, E.A., VisLobokova, I.A. \& Sotnikova, M.V. (1998): Large Ruscinian Mammalia in the Territory of the Former Soviet Union. - Stratigraphy and Geological Correlation, 6 (4): 368-382.

VeKUA, A. (1995): Die Wirbeltierfauna des Villafranchium von Dmanisi und ihre biostratigraphische Bedeutung. Jahrbuch des Römisch-Germanischen Zentralmuseums Mainz, 42 (1): 77-180.

VISLовокоVA, I.A. (1980): On systematical position of the deer from Pavlodar and the origin of Neocervines. Palaeontological Journal, 3: 91-106 [in Russian].

VISLOвокоVA, I.A. (1990): Fossil Deer of Eurasia. - Transactions of the Palaeontological Institute, 240: 1-206 [in Russian]. Vos, J. DE, MOL, D. \& ReUmeR, J.W.F. (1995): Early Pleistocene Cervidae (Mammalia, Artiodactyla) from the Oosterschelde (the Netherlands), with a revision of the cervid genus Eucladoceros FALCONER, 1868. - Deinsea, 2: 95-121.

WANG, L.-H. \& ZHANG, Z.-Q. (2014): Late Miocene Cervavitus novorossiae (Cervidae, Artiodactyla) from Lantian, Shaanxi Province. - Vertebrata PalAsiatica, 7: 303-315.

Manuscript received: November 14th, 2016.

Revised version accepted by the Stuttgart editor: December 20th, 2016.

\section{Address of the author:}

Roman Croitor, Aix-Marseille University, CNRS, UMR

7269, MMSH BP674, 5, rue du Château-de-l'Horloge, 13094

Aix-en-Provence, France \& Institute of Zoology, Academy

of Sciences of Moldova, Academiei str. 1, 2028 Chișinău,

Republic of Moldova;

e-mail: romancroitor@europe.com 
Table 1. Praeelaphus australorientalis ssp. nov.: measurements of the skull from.

\begin{tabular}{|c|c|c|c|c|c|c|c|c|c|}
\hline \multirow{3}{*}{$\begin{array}{l}\text { Measurements } \\
\text { side } \\
\end{array}$} & \multicolumn{3}{|c|}{$\begin{array}{c}\text { Praeelaphus } \\
\text { australorientalis }\end{array}$} & \multirow{2}{*}{\multicolumn{2}{|c|}{$\begin{array}{c}\text { Praeelaphus } \\
\text { lyra IGF1933v } \\
\text { (holotype), } \\
\text { Ponte a Elsa }\end{array}$}} & \multirow{3}{*}{$\begin{array}{l}\text { Praeelaphus } \\
\text { cf. lyra } \\
\text { IGF1378 } \\
\text { (Olivola) } \\
\\
\sin \\
\end{array}$} & \multicolumn{2}{|c|}{$\begin{array}{l}\text { Praeelaphus } \\
\text { warthae }\end{array}$} & \multirow{3}{*}{$\begin{array}{c}\text { Praeelaphus } \\
\text { perrieri } \\
\text { (neotype), } \\
\text { Etouaires } \\
\\
d x \\
\end{array}$} \\
\hline & \multicolumn{2}{|c|}{$\begin{array}{c}\text { Velikoploskoe } \\
\text { OF24995 } \\
\text { (holotype) } \\
\end{array}$} & \multirow{2}{*}{$\begin{array}{c}\text { Beresti, } \\
\text { Nr. } 231 \\
d x\end{array}$} & & & & \multirow[t]{2}{*}{$\begin{array}{l}\text { Nr. } 1 \text { (holo- } \\
\text { type) Weze }\end{array}$} & \multirow[t]{2}{*}{$\begin{array}{c}\text { Nr. } \\
362 \\
\text { Weze }\end{array}$} & \\
\hline & $\sin$ & $d x$ & & $\sin$ & $d x$ & & & & \\
\hline $\begin{array}{l}\mathrm{H} \text { of first } \\
\text { ramification }\end{array}$ & & 105.0 & & 65.8 & 61.7 & 69.5 & & & 82.7 \\
\hline $\begin{array}{l}\text { L between first } \\
\text { and second } \\
\text { ramifications }\end{array}$ & & 78.0 & & 480.0 & 455.0 & 420.0 & & & 393.0 \\
\hline $\begin{array}{l}\text { L between } \\
\text { second and third } \\
\text { ramifications }\end{array}$ & 235.0 & & & 350.0 & 320.0 & & & & 215.0 \\
\hline DAP antler burr & 55.5 & 51.8 & 57,1 & & & & & & 68.0 \\
\hline DLM antler burr & 55.8 & 56.8 & 43.6 & & & & & & 66.0 \\
\hline DAP above burr & 42.4 & 40.3 & 32.0 & 34.0 & 35.3 & 39.8 & & & 59.0 \\
\hline DLM above burr & 43.3 & 43.1 & 38.0 & 33.4 & 32.1 & 40.7 & & & 48.1 \\
\hline DAP pedicle & 31.7 & 31.9 & 25,9 & 24.7 & 25.7 & 32.7 & & & 42.7 \\
\hline DLM pedicle & 35.6 & 36.7 & 32.0 & 30.0 & 29.7 & 37.3 & & & 45.5 \\
\hline L pedicle medial & 24.5 & 21.1 & 24.0 & 27.4 & 25.0 & 23.5 & & & 36.0 \\
\hline $\begin{array}{l}\text { L pedicle from } \\
\text { orbit }\end{array}$ & 63.2 & & & & & & & & \\
\hline Frontal breadth & \multicolumn{2}{|c|}{$\frac{1}{94.1}$} & & \multicolumn{2}{|c|}{108.0} & & 104.0 & & \\
\hline $\begin{array}{l}\text { L bregma - } \\
\text { sigmoid suture }\end{array}$ & \multicolumn{2}{|c|}{53.3} & & & & & & & \\
\hline $\begin{array}{l}\text { L bregma - } \\
\text { opisthocranion }\end{array}$ & \multicolumn{2}{|c|}{70.0} & & & & 76.0 & & & \\
\hline $\begin{array}{l}\text { Breadth of } \\
\text { neurocranium }\end{array}$ & \multicolumn{2}{|c|}{75.5} & & & & 82.0 & 76.6 & & \\
\hline $\begin{array}{l}\text { Breadth of } \\
\text { occiput }\end{array}$ & \multicolumn{2}{|c|}{95.7} & & & & & & 89.0 & \\
\hline $\begin{array}{l}\text { Height of occiput } \\
\text { (basion- } \\
\text { opisthocranion) }\end{array}$ & \multicolumn{2}{|c|}{62.0} & & & & 64.5 & & 68.5 & \\
\hline $\begin{array}{l}\text { Breadth of } \\
\text { occipital condyles }\end{array}$ & \multicolumn{2}{|c|}{50.4} & & & & 58.5 & & 57.0 & \\
\hline $\begin{array}{l}\text { Breadth of } \\
\text { basioccipitale at } \\
\text { pharyngeal } \\
\text { tuberosities }\end{array}$ & \multicolumn{2}{|c|}{28.4} & & & & 33.5 & & 29.0 & \\
\hline $\begin{array}{l}\text { DAP bulla } \\
\text { tympani }\end{array}$ & 12.9 & 13.2 & & & & & & 15.5 & \\
\hline $\begin{array}{l}\text { L bulla tympani } \\
\text { with auditory } \\
\text { tube }\end{array}$ & 27.5 & 30.4 & & & & & & & \\
\hline
\end{tabular}


Table 2. Comparison of neurocranium measurements and proportions of small-sized Plio-Pleistocene and modern deer of subfamily Cervinae: 1 , breadth of occiput; 2 , width of occipital condyles; 3 , occiput height (distance between basicranion to opisthocranion); 4, frontal breadth (in males: the narrowest point between orbits and pedicles); 5 , width of braincase (in males: cranial width behind pedicles); 6 , width of basioccipitale at pharyngeal tuberosities; 7 , distance between bregma and opisthocranion.

\begin{tabular}{|c|c|c|c|c|c|c|c|c|c|c|c|}
\hline Species & Specimen ID & 1. & 2. & 3. & 4. & 5. & 6. & 7. & $\begin{array}{l}7 / 5 \\
\%\end{array}$ & $\begin{array}{l}3 / 1 \\
\%\end{array}$ & $\begin{array}{l}5 / 4, \\
\%\end{array}$ \\
\hline $\begin{array}{l}\text { Praeelaphus } \\
\text { australorientalis }\end{array}$ & OF24935 O" & 95.7 & 50.4 & 62.0 & 94.1 & 75.5 & 28.4 & 70.0 & 107.9 & 64.8 & 80.2 \\
\hline $\begin{array}{l}\text { Praeelaphus } \\
\text { warthae }\end{array}$ & Nr. 1 ơ, Weze & & & & 104.0 & 76.6 & & & & & 73.7 \\
\hline Praeelaphus cf. lyra & IGF1378 ơ, Olivola & & 58.5 & 64.5 & & 82.0 & & 76.0 & 107.9 & & \\
\hline $\begin{array}{l}\text { Metacervocerus } \\
\text { rhenanus }\end{array}$ & $\begin{array}{l}\text { CEY2318 o", } \\
\text { Ceyssaguet }\end{array}$ & & & & 98.8 & 82.8 & & & & & 83.8 \\
\hline $\begin{array}{l}\text { Metacervocerus } \\
\text { rhenanus }\end{array}$ & $\begin{array}{l}\text { CEY15194 o", } \\
\text { Ceyssaguet }\end{array}$ & & & & 104.6 & 82.2 & & 79.5 & 103.4 & & 78.6 \\
\hline $\begin{array}{l}\text { Metacervocerus } \\
\text { rhenanus }\end{array}$ & $\begin{array}{l}\text { CEY11217 o", } \\
\text { Ceyssaguet }\end{array}$ & 97.0 & 58.0 & 66.7 & 103.1 & 77.7 & 41.1 & 74.3 & 104.6 & 68.8 & 75.4 \\
\hline $\begin{array}{l}\text { Metacervocerus } \\
\text { rhenanus }\end{array}$ & $\begin{array}{l}\text { No.496536 on, St. } \\
\text { Vallier }\end{array}$ & 86.7 & 50.7 & 56.0 & 85.4 & 75.9 & 30.5 & 68.5 & 110.8 & 64.6 & 88.9 \\
\hline $\begin{array}{l}\text { Metacervocerus } \\
\text { rhenanus }\end{array}$ & $\begin{array}{l}\text { No,210638 } \%, \\
\text { Seneze }\end{array}$ & 73.0 & 51.8 & 62.8 & & & 36.7 & 75.0 & & 86.0 & \\
\hline Muntiacus muntjac & C780 O' & 56.6 & 32.7 & 41.0 & 61.0 & 52.0 & 20.3 & 47.0 & 110.6 & 72.4 & 85.2 \\
\hline Muntiacus reevesi & $\mathrm{C} 782 \mathrm{O}^{\mathrm{n}}$ & 58.1 & 31.4 & & 62.2 & 51.7 & & 48.7 & 106.2 & & 83.1 \\
\hline Axis axis maculatus & BM- 67.4.12.240 O" & 87.3 & 50.3 & 54.8 & 91.0 & 72.0 & 34.7 & 72.7 & 99.0 & 62.8 & 79.1 \\
\hline Axis axis & $\begin{array}{l}\text { BM- 697-t o", South } \\
\text { Germany }\end{array}$ & 83.7 & 53.7 & 60.5 & 96.3 & 74.6 & 37.0 & 74.2 & 100.5 & 72.3 & 77.5 \\
\hline Axis axis & BM- 1845.1.8.195 ᄋ & 79.6 & 46.2 & 53.7 & & 68.1 & 33.0 & 70.4 & 96.7 & 67.5 & \\
\hline Axis axis & C12089 ơ & & & & 95.6 & 72.4 & & 77.0 & 94.0 & & 75.7 \\
\hline Hyelaphus porcinus & BM-27.12.14.106 O' & 93.0 & 42.5 & 53.1 & 80.0 & 64.6 & 33.3 & 66.7 & 96.9 & 57.1 & 80.8 \\
\hline Hyelaphus porcinus & BM-79.11.21.188 O" & 80.0 & 43.4 & 53.0 & 73.1 & 62.2 & 33.8 & 63.6 & 97.8 & 66.3 & 85.1 \\
\hline Hyelaphus porcinus & BM 27.2.14.100 o" & 90.2 & 43.8 & 55.0 & 79.1 & 68.5 & 37.7 & 67.6 & 101.3 & 61.0 & 86.6 \\
\hline Hyelaphus porcinus & $\begin{array}{l}\text { BM-1858.12.102 }, \\
\text { Ceylon }\end{array}$ & 74.0 & 39.5 & 45.0 & & 62.5 & 27.3 & 61.0 & 102.5 & 60.9 & \\
\hline Hyelaphus porcinus & BM-206.7.59 \& & 72.8 & 39.8 & 49.3 & & 61.8 & 29.1 & 55.2 & 112.0 & 67.7 & \\
\hline Cervus nippon & $\begin{array}{l}\text { BM66.165 } \% \text {, } \\
\text { England }\end{array}$ & 71.7 & 47.8 & 52.0 & & 66.4 & 27.6 & 69.4 & 95.8 & 72.5 & \\
\hline Cervus nippon & BM 72.1060 ㅇ & & 50.3 & 59.0 & & 76.5 & 31.3 & 68.0 & 112.5 & & \\
\hline Cervus nippon & $\mathrm{nn}, \mathrm{BM} \mathrm{O}^{n}$ & 111.0 & 61.1 & 70.5 & 105.5 & 84.5 & 42.9 & 79.2 & 106.7 & 63.5 & 80.1 \\
\hline Cervus nestii & IGF1403 o", Olivola & 98.2 & 60.0 & 60.8 & 102.3 & 81.0 & 38.0 & 78.8 & 102.8 & 61.9 & 79.2 \\
\hline Cervus nestii & IGF243 o", Figline & & & & 92.9 & 79.3 & 37.0 & 72.5 & 109.4 & & 85.4 \\
\hline $\begin{array}{l}\text { Cervus elaphus } \\
\text { acoronatus }\end{array}$ & NMENH O", Tiraspol & 148 & 82,9 & 96,6 & 133,3 & 114,3 & 44,2 & 94 & 121.6 & 65.3 & 85.7 \\
\hline $\begin{array}{l}\text { Cervus elaphus } \\
\text { acoronatus }\end{array}$ & $\begin{array}{l}\text { NMENH- } 7996 \text { } 9 \text {, } \\
\text { Dubasari }\end{array}$ & 119,5 & 72,7 & 86,8 & & 99,3 & & 86,3 & 115.1 & 72.6 & \\
\hline $\begin{array}{l}\text { Cervus elaphus } \\
\text { corsicanus }\end{array}$ & $\begin{array}{l}\text { C11932 ơ, Cairo, } \\
\text { Sardegna }\end{array}$ & 102 & 51,1 & 66,5 & 98,8 & 88 & 37,3 & 75,2 & 117.0 & 65.2 & 89.1 \\
\hline $\begin{array}{l}\text { Cervus elaphus } \\
\text { barbarus }\end{array}$ & P-1868-2 ơ, Algeria & & 59,7 & & 106,3 & 77,8 & & 72,3 & 107.6 & & 73.2 \\
\hline Cervus elaphus & C11855 ơ, Toscana & & 62,8 & 81,3 & 114 & 97,3 & & 90,3 & 107.8 & & 85.4 \\
\hline Panolia eldi & P-1937-157 Q & 81,3 & 52,2 & 56 & & 63 & & 74 & 85.1 & 68.9 & \\
\hline
\end{tabular}


Neues Jahrbuch für Geologie und Paläontologie - Abhandlungen, 283/1, 85-108 - Stuttgart, January 2017

\begin{tabular}{|c|c|c|c|c|c|c|c|c|c|c|c|}
\hline Rucervus duvaucelii & $\begin{array}{l}\text { C12088 O", Central } \\
\text { India }\end{array}$ & & & & 111,6 & 80,6 & 36,2 & 93,5 & 86.2 & & 72.2 \\
\hline Rucervus duvaucelii & P-1864-4 우 & 108,5 & 58,6 & 71,5 & 89 & 65,7 & & & & 65.9 & 73.8 \\
\hline $\begin{array}{l}\text { Elaphurus } \\
\text { davidianus }\end{array}$ & P-1972-67 O & 105,9 & 64,4 & 73,7 & 103 & 82,7 & & 97 & 85.3 & 69.6 & 80.3 \\
\hline Dama dama & $\begin{array}{l}\text { BM 47.1.1.4 o", } \\
\text { England }\end{array}$ & 100,4 & 58,4 & 65 & 104,4 & 77,4 & 42 & 83,8 & 92.4 & 64.7 & 74.1 \\
\hline Dama dama & $\begin{array}{l}\text { BM 47.12.11.1 } \sigma^{*}, \\
\text { England }\end{array}$ & 93,5 & 52,3 & 62,8 & 100,4 & 80 & 38,7 & 73,6 & 108.7 & 67.2 & 79.7 \\
\hline Dama dama & $\begin{array}{l}\text { BM 1936.11.3.1 O", } \\
\text { Sussex }\end{array}$ & 99 & 50,3 & 63 & 102,2 & 82,3 & 42,3 & 87,3 & 94.3 & 63.6 & 80.5 \\
\hline Dama dama & C12058 ơ, Italy & 101 & 54,5 & 61 & 98,6 & 86,4 & 45,8 & 81 & 106.7 & 60.4 & 87.6 \\
\hline Dama dama & C12061 ơ, Italy & & & & 99,3 & 81,6 & 32,6 & 85 & 96.0 & & 82.2 \\
\hline Dama dama & C12063 ơ, Italy & 89,5 & 51,2 & 59,8 & 91,8 & 74,4 & 36 & 78 & 95.4 & 66.8 & 81.0 \\
\hline Dama dama & C12059 ơ, Italy & 94 & 76,8 & 56,6 & 93 & 77,4 & 40,7 & 79 & 98.0 & 60.2 & 83.2 \\
\hline Dama dama & C1262 o", Italy & 93,6 & 54,1 & 59,4 & 100,7 & 78 & 40,8 & 83 & 94.0 & 63.5 & 77.5 \\
\hline Dama dama & C12202 \&, Italy & 85 & & & & 71,3 & & 77,6 & 91.9 & & \\
\hline Dama dama & $\begin{array}{l}\text { BM 67.4.12.24 Q, } \\
\text { Anatolia }\end{array}$ & 81 & 48,2 & 56,7 & & 71,5 & 32,7 & 72,3 & 98.9 & 70.0 & \\
\hline Dama dama & $\begin{array}{l}\text { BM 1937.3.10.2 }, \text {, } \\
\text { England }\end{array}$ & 80,1 & 48,5 & 53,8 & & 69 & 34,2 & 71,8 & 96.1 & 67.2 & \\
\hline Dama dama & $\begin{array}{l}\text { BM 1937.6.9.1 Q, } \\
\text { England }\end{array}$ & 83 & 49 & 55,1 & & 72,9 & 34,1 & 71,7 & 101.7 & 66.4 & \\
\hline Dama dama & $\begin{array}{l}\text { BM 693-q } ᄋ, \\
\text { Germany }\end{array}$ & 83,8 & 50,7 & 58,5 & & 73 & & 73,5 & 99.3 & 69.8 & \\
\hline
\end{tabular}

